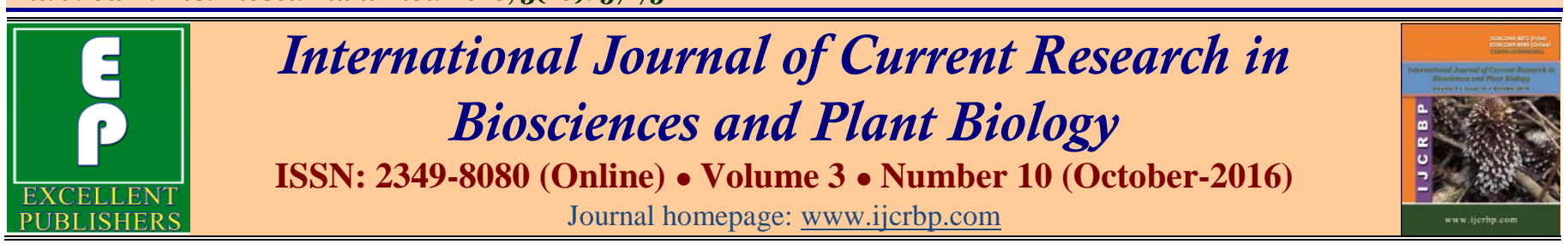

Original Research Article

doi: http://dx.doi.org/10.20546/ijcrbp.2016.310.008

\title{
The Socio Economic and Environmental Impacts of Firewood Exploitation from the Ndjamena Supply Basin as Wood Energy (Chad)
}

\author{
Tchobsala*, Ibrahim Adamou and Kebeyei Noé
}

Biodiversity Laboratory and Sustainable Development, Faculty of Science Department of Biology Science, The University of Ngaoundéré, P.O. Box 454 Ngaoundéré, Cameroon

*Corresponding author.

\begin{abstract}
A bstract
This research aims to examining: i) the domestic energy source used by local population, ii) the causes and appropriate moment of firewood exploitation, iii) the impact of firewood exploitation on the floristic composition and structure and ecological characterization of the vegetation, iv) look for ways and means of cogestion for a development plan for firewood exploitation The socio economic surveys were carried out with the help of 210 people some different market selected. The floristic note were achieved by the transect method. The experimental devise is a split plot with 4 factors (formation of vegetation) 3 processing's (particles) and 3 sites (villages) in each village. 12 portions of $50 \mathrm{~m} \times 50 \mathrm{~m}$ were delimited and located with the help of some stakes for chest height. The result pointed out that agriculture $(95.83 \%)$ and the need in firewood $(52.83 \pm 23.93)$ are the mains causes of firewood exploitation. The drop in vegetation and fall in forestry non woody species product $(75.8 \%)$ and the temperature increase $(74.0 \%)$ were the consequence of exploitation of firewood. The variety indices of the floristic resources are higher in virgin forest than in gallery forest but lower in shrub savannahs where deforestation is considerable. The vegetation structure was an "L" form with a good regeneration of new growing trees. A development plan was set up for a sustainable management of the platform.
\end{abstract}

\section{Introduction}

The African continent has about 520 million hectares of world forests. It is a genuine biodiversity reserve (FAO, 1998). More than 800 million of inhabitants, mostly poor, rely on the forest for their nutrition, health, habitats as well as for their financial income. In central Africa, the last demographic boom reported these last decades have negative consequences on the environment because available natural resources are insufficient (PalmbergLerrche, 1997; Antonios, 2002). The demand is higher than the supply because the demographic boom is really considerable (Hien et al., 1994; Diop, 2000). In view of this demand more than 800 million of people among whom 180 million living in developing countries suffer from famine and malnutrition (Diop, 2000). The population entirely depends on his living environment and this disrupts the ecological functioning of natural ecosystems leading to the extinction of many species (Wanders, 2000). In the Chad republic, close to $90 \%$ of completed final energy come from woody biomass. Household energy resources (firewood, charcoal) are drowning for more than $95 \%$ from natural and biological environment (AEDE, 2002). 
A part from food necessity, the national biological diversity underlie more than 4 million people unable to have access to adequate modern medical health care and are obliged to resort to traditional pharmacopeia through pathetic purchasing power. The annual domestic energy consumption is estimated to more than 1450000 cubic meters (AEDE, 2002). This fuel source come from surrounding areas called (supply in basin in Ndjamena in wood energy sector) stretches over about 7.5 million hectares. This supplying basin is under extinction threat due to the high pressure action. The Chadian government has set up many projects programs and forum for the support and management of the environment with the signing of an agreement during the Rio de Janeiro summit in 1992. This agreement is characterized by the adoption and promulgation of the lows $\mathrm{N}^{0} 36 / \mathrm{PR} / 94$ and 20/12/94, low $\mathrm{N}^{0} 014 / \mathrm{PR} / 98$ of $17 / 08 / 2008$ of $10 / 06 / 2008$ leaving respectively on the organization, commercialization and the wood transportation in big cities and finally to the taxation related to it; defining the main principles of environment protection and on forest regulations, the fauna and halieutic resources. Unfortunately the classical management attempts of forestry resources handling even the one known as participative, exclusively assured by public administration agent without concrete implication of local communities were doomed to failure to the country. Research works were carried out on the environmental level particularly the AEDE in 2002 on the supplying guiding principle regarding domestic energy in Ndjamena.

The FAO respectively in 2001, 2011and 2012 laid emphasis on the development strategies and the plan of action for the urban and per urban forestry promotion in Ndjamena town, on the support program to the formulation of a strategy of a forestry plan of action in the urban and per urban of Ndjamena town and also on the WINDOM platform in the same town. Most of the research works were carried on the demand production export and the domestic energy consumption, but no research work was carried out to identify the involve actors, the times the cause and the consequences of the firewood exploitation so as to assess the financial and quantitative approaches of firewood course of study as well as the examine the ecological and structures of the firewood of the different formation of vegetation under the influence of firewood exploitation and lastly to make out a stock list of a joint management accepted in the country.

\section{Materials and methods}

\section{The presentation of the study area}

The survey was done in three villages, namely Dourbali, Karnak and Bodro some localities situation in the South East of the Ndjamena wood energy supply basin stretching over a distance of 7.5 million hectares and comprising 33 cantons divided into 4 division (Mayo Boney, Dahaba, Baguirmi and Hadjar el Hamis (Fig. 1).

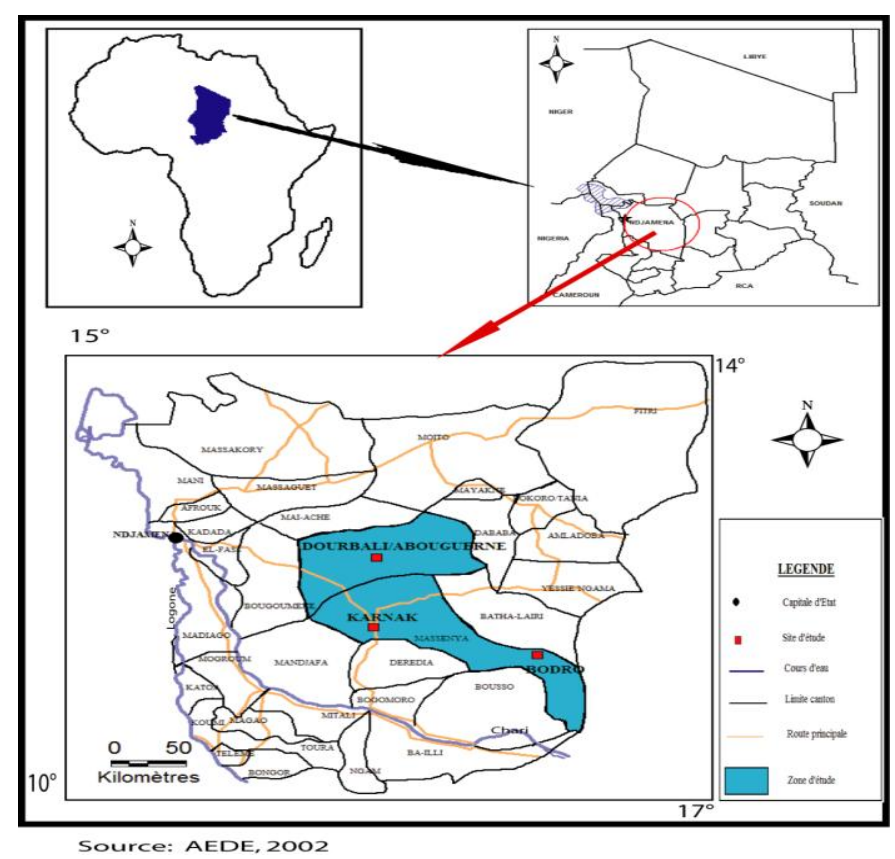

Fig. 1: Localization of the study site.

Dourbali a locality situated $96 \mathrm{Km}$ from the capital Ndjamena is situated between the $11^{\text {th }} / / 47^{\prime}$ and the $15^{\text {th }}$ //52'. The position of that village is $\pm 7 \mathrm{~m}$ higher. The surface area of this village is estimated at more than $20,000 \mathrm{~km}^{2}$ with a population of 77.787 among whom 39303 men and 38.484 women (INSEE, 2009). The dominant ethnic groups are the Arabs and the Baguirmi. The Karnak village is situated about $128 \mathrm{Km}$ from the Ndjamena town and on the geographic plan, it is located between the $11^{\text {th }} / / 33$ and $16^{\text {th }} 1604$. Its surface area is estimate at $3500 \mathrm{Km}^{2}$ and the 13.000 inhabitants. The dominant ethnic group is the Baguirmi. Lastly the Bodro village is $210 \mathrm{Km}$ from Ndjamena town and from the Massenya subdivision. It is located between the $11^{\text {th }} / / 44$ and $17^{\text {th }} 27^{\prime}$ with a $\pm 14 \mathrm{~m}$ geographic position and a 6.08 geographic high. The Sahelo-Sudanian climate is the main characteristic of the village (with a pluviometer of 600 to $800 \mathrm{~mm}$ ) its surface area is estimated at $7.500 \mathrm{~km}^{2}$ with a population of 21000 (AEDE, 2002). 


\section{Socio-economic enquires}

They were carried out with the help of 40 households and 30 people in some market and the exploitation area per village, giving a total of 120 household and 90 people in some markets and some firewood exploitation areas. The type of interview carried out is known as the semi structured one with exclusive questions (a yes or no question), open questions (the answer depend on the deliberate point of view and biased question (where few answers are provided to the guarantors). The great categories of the questionnaires were applied on one hand to the quantitative approaches and the beneficiaries and on the other hand to the socio economic and environmental influences of firewood exploitation. Those investigations were carried out with thanks to some questionnaires prepared beforehand in some sample enquiry forms.

\section{Environmental parameter list}

The choice of the testing plots (concrete environment and vegetation) takes into consideration the adequate dimensions that can accommodate the sample of some representative species, of some plant groups, the uniformity of some formation of vegetation excluding buffer zone, the heterogeneity of the selected vegetation of an appropriated surroundings an access lane. For the physical environment of the collecting data base form were prepared in advance to characterize vegetation of the environment. For the floristic data base, the minimal area ways of experimentations implemented successfully by Yonheu (1993) and Tchobsala (2011) on the vegetation of Adamawa savannah (Cameroon). It consisted to delimit with the help of decameter ribbon surface area of $50 \mathrm{~m} \times 50 \mathrm{~m}$ within which a stocktaking of vegetation was carried out following a 10 meters radius width and $50 \mathrm{~m}$ length simultaneous. The experimental system design is a split plot factor (of formation of vegetation), three (3) handling (of plot) and three coaching's (in some villages). In each village, a total of 12 coaching's of $50 \mathrm{~m} \times 50 \mathrm{~m}$ were demarcated and pinpointed with the help of some stakes, giving a total of 36 coaching for the three villages. On each coaching, the woody species with $\geq 10 \mathrm{~cm}$ circumference and the one with $10 \mathrm{~cm}$ were listed. The data base collecting focused on the one with a chest high (DHP), the radius and the high of the bunch in the woody species of $\geq 10 \mathrm{~cm}$ circumference; the number of feet for the woody with $<10 \mathrm{~cm}$ circumference. To estimate the health gauges of vegetation (mortality, graze, twisting, marks, natural felling areas, etc.), the Ouedrago and Zahongo (2003) method was used. This method consisting in observing and counting the number of feet of distorted species out of the total number of species in a given coaching. The stock taking of the herbaceous species took into cognition the presence of some species in each area of $50 \mathrm{~m} \times 50 \mathrm{~m}$.

\section{Methods of data based analysis}

The index frequency exploited by Braun-Blanquet (1932), was accepted for calculation of the frequency of species in several formation of vegetation. The absolute frequency of species is the number of the data based collection packaging that specie. The relative frequency is the represent proportion in term of percentage between the number of the data based collection packaging that specie and the total number of data based collection time 100. This method aims at determining the accidental species; accessory, incidental species, enough species frequent, frequent species and very frequent (Table 1).

Table 1. Frequencies indices of Braun-Blanquet (1932).

\begin{tabular}{lll}
\hline Indices & Frequency & Type of species \\
\hline I & $\mathrm{F}<20$ & Accidental species \\
II & $20<\mathrm{F}<40$ & Incidental species \\
III & $40<\mathrm{F}<60$ & Enough species frequent \\
IV & $60<\mathrm{F}<80$ & Frequent species \\
V & $80<\mathrm{F}<100$ & Very much frequent species \\
\hline
\end{tabular}

\section{Relative density}

The relative density (DRe) or relative abundance is the relation between the number of the subjects, of species and the total number of all the subject of all the species found in the area considered as multiplied by 100 .

\section{Relative absolute dominance}

The dominance expresses the influence exercised by the species community. The relative dominance (RD) is the relation between the earth surface or basal surface (sb) of a species over the total earth surface of all the subject found in the area, $\mathrm{Sb}=\pi \mathrm{D} 2 / 4$. $\mathrm{D}$ is the stem diameter.

\section{The relative importance value of Curtis}

It is the total amount of the relative's frequency, the abundance and density.

\section{The floristic diversity indexes}

The diversity index of Shannon: (ISH $=-\sum \mathrm{Ni} / \mathrm{N} \log _{2}$ $(\mathrm{Ni} / \mathrm{N})$; where, $\mathrm{Ni}$ is the number of species. 
The fairness (EQ) of Piélou (1966): EQ = ISH/ $\log _{2} \mathrm{~N}$

The diversity index of Simpon:

$\mathrm{D}=1 / \sum_{2}(\mathrm{Ni} / \mathrm{N})^{2}$ (Begon et al., 1987); where, $\mathrm{D}^{\prime}=$ $\sum(\mathrm{Ni} / \mathrm{N})^{2}$.

\section{The data based analysis techniques}

The variance analysis (ANOVA) was carried out with the help of Statgraphic.5 software. The parameter analysis significance was selected for the elaboration of the main, component analysis (MCA) and the organized ascendant classification (OAC) with the help of the XLSTAT software.

\section{Results}

\section{Domestic energy source used by local population}

Fig. 2 shows a high used of fire wood (83\%) in the households of the three investigate villages. It is the main energy source available for the local population. They exploited $(11 \%)$ of wood charcoal in the households. The paraffin (5\%) and the color gas (1\%) are poorly used by the local population because of the financial mean shortages.

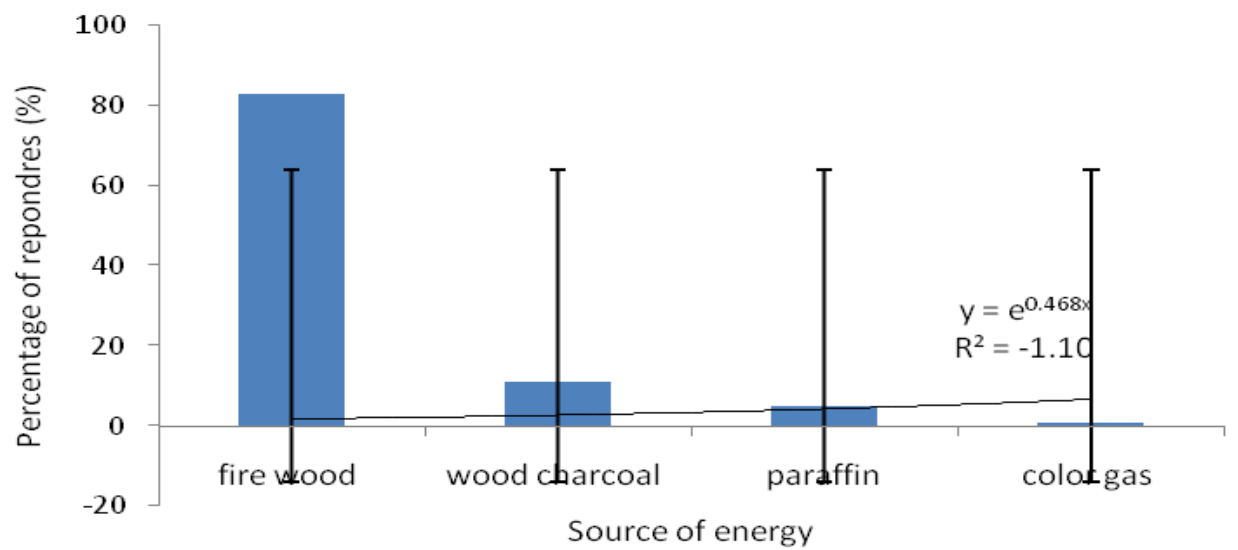

Fig. 2: Types of exploited domestic energy-actors of the firewood field.

\section{Actors of firewood exploitation}

Seven (7) groups of actors are involved in the firewood exploitation at the level of the N'djamena supply basin in the wood-energy sector in the Chad and particularly in three villages, namely (Dourbali, Karnak and Bodro) (Table 2). Investigation with local populations pointed out that firewood consumers $(47.33 \%)$ are numerous in the exploitation of firewood in the survey area. In fact, the seven groups of actors are first of all firewood consumers and that fact justifies the high percentage rate of the guarantors. They are closely followed by the firewood producers (19.67\%). The first two actors were different from producers-transporters-shop keepers $(4.33 \%)$ and the market retailers $(3.67 \%)$. In the fact most of the producers and consumers are local population and are more involved in firewood exploitation for their survival. There is significant difference $(p=0.005)$ between the consumers and producer and non-significant difference among the other actors of firewood exploitation. According to those villages, there is a negligible difference among the guarantors. The consumers are great in numbers $(51 \%)$ in Karnak while the producers are more found in the Bodro locality $(21 \%)$ and the retailer-debtors with a rate of $(10 \%)$ in the Dourbali locality.

Table 2. Actors of firewood exploitation in terms (\%).

\begin{tabular}{lllll}
\hline Actors & Dourbali & Karnak & Bodro & Mean \\
\hline Consumers & 47.00 & 51.00 & 44.00 & $47.33 \pm 3.51^{\mathrm{a}}$ \\
Producers & 18.00 & 20.00 & 21.00 & $19.67 \pm 1.53^{\mathrm{b}}$ \\
Shopkeepers-producers & 8.00 & 9.00 & 11.00 & $9.33 \pm 1.53^{\mathrm{c}}$ \\
Retailer-debtors & 10.00 & 6.00 & 8.00 & $8.00 \pm 2.00^{\mathrm{c}}$ \\
Wholesalers & 6.00 & 8.00 & 9.00 & $7.67 \pm 1.53^{\mathrm{c}}$ \\
Producers-transporters-shopkeepers & 7.00 & 4.00 & 2.00 & $4.33 \pm 2.52^{\mathrm{d}}$ \\
Market-retailers & 4.00 & 2.00 & 5.00 & $3.67 \pm 1.53^{\mathrm{d}}$ \\
Total & 100.00 & 100.00 & 100.00 & 100.00 \\
\hline
\end{tabular}

Assigned figures of the same letters are not significant up to 0.05 thresholds. 
Distribution of firewood farmers according to their sexes and age ranges

Firewood exploitation actors vary according to their age and sex. Table 3 shows a high proportion rate of men $(82 \%)$ active in the firewood exploitation compared to women who represent only (37\%). This sex discrimination can be explained by the fact that firewood exploitation is tiresome and risky for women, because this practice needs a lot of physical efforts.

The population whose age range is $32-42$, representing $53 \%$ generates a significant quantity of firewood. This can be explained by the fact that within this age range, the population has reached maturity and are physically strong enough for firewood exploitation.

Table 3. Distribution of firewood farmers according to their sexes and age ranges $(\%)$. $\mathrm{Bc}(+)=$ population exploiting firewood.

\begin{tabular}{lllllll}
\hline Age- range & $\begin{array}{l}\text { Men } \\
\text { Number }\end{array}$ & Bc $(+)$ & $\begin{array}{l}\text { Women } \\
\text { Number }\end{array}$ & Bc (+) & $\begin{array}{l}\text { Tot } \\
\text { Number }\end{array}$ & Bc (+) \\
\hline$[10-20]$ & 11 & 3 & 13 & 5 & 24 & 8 \\
{$[21-31]$} & 32 & 16 & 20 & 8 & 52 & 24 \\
{$[32-42]$} & 68 & 53 & 24 & 19 & 92 & 72 \\
{$[43-53]$} & 20 & 8 & 12 & 5 & 32 & 13 \\
{$[\geq 54]$} & 6 & 2 & 4 & 0 & 10 & 2 \\
Total & 137 & 82 & 73 & 37 & 210 & 119 \\
\hline
\end{tabular}

\section{The causes of firewood exploitation in the three} villages

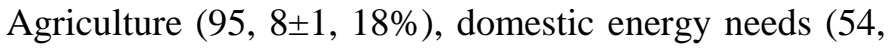

$17 \pm 3,12 \%)$ and demand in firewood $(52,83 \pm 23,93 \%)$ show highly significant differences $(\mathrm{P}=0,001)$ and are therefore respectively the main causes of firewood exploitation (Table 4).

Table 4. Answers of the causes of firewood exploitation according the local population (\%).

\begin{tabular}{lllll}
\hline Exploitation for & Dourbali & Karnak & Bodro & Mean \\
\hline Agriculture & 97.5 & 95 & 95 & $95.83 \pm 1.18^{\mathrm{a}}$ \\
Domestic energy needs & 57.5 & 55 & 50 & $54.17 \pm 3.12^{\mathrm{b}}$ \\
Firewood & 55 & 81 & 22.5 & $52.83 \pm 23.93^{\mathrm{b}}$ \\
Parent heritage & 60 & 32.5 & 40 & $44.17 \pm 11.61^{\mathrm{b}}$ \\
Poverty & 45 & 35 & 35 & $38.33 \pm 4.71^{\mathrm{b}}$ \\
High cost of living & 35 & 24 & 30 & $29.67 \pm 4.50^{\mathrm{b}}$ \\
Urbanisation & 5 & 15 & 62 & $27.33 \pm 24.85^{\mathrm{b}}$ \\
Profession & 35 & 27.5 & 15 & $25.83 \pm 8.25^{\mathrm{b}}$ \\
Unemployment & 25 & 22.5 & 10 & $19.17 \pm 6.56^{\mathrm{c}}$ \\
Others & 2.5 & 2.5 & 5 & $3.33 \pm 1.18^{\mathrm{d}}$ \\
\hline
\end{tabular}

Assigned figures of the same letters are not significant up to 0.05 threshold.

\section{Firewood exploitation periods}

The highest firewood exploitation period runs from December to April with a percentage rate of $99 \%$ (Fig. 3). As from April, the firewood exploitation progressively decreases and almost becomes void from June to October. The cutting down of trees activity starts in December. The highest exploitation moment is explained by the drop in the agricultural activities. During this period, the population is in search for firewood either for consummation or marketing. Throughout this period equally, access ways during rainy seasons for firewood fetching is difficult and within these six months (from June to November), the population devote themselves to agriculture and harvesting.

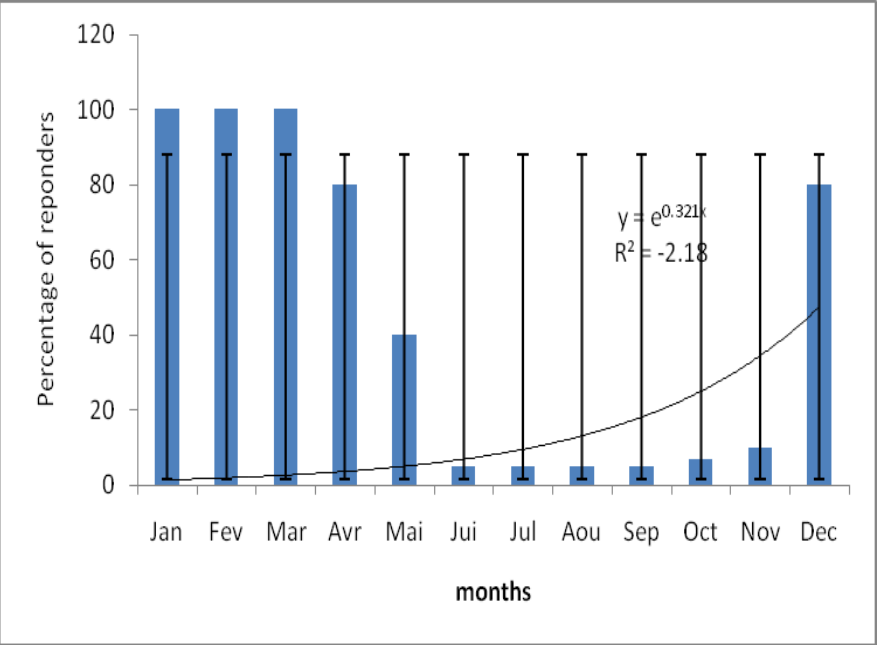

Fig. 3: Firewood exploitation periods (\%). 
Firewood production, consumption and expert in the area of research

During the four months of intense firewood exploitation, the population produced 246.894 cubic meters per year. The average consumption rate is evaluated to 53945.28 cubic meters per year and export 192948.71 cubic meters/year of firewood in the Bodro village (Table 5).

These values are higher than those of the other villages. This difference can be explained by the availability in some resources in the Bodro village. The firewood export (116976.9 cubic meters/year) is more important than the consumption of the firewood (2698.09 cubic meters/year) and to the product on (143962.00 cubic meters/year) in the three villages. These results show that the three villages export and sell firewood to the N'djamena population or in other cities to have more profit.

The average daily /person /day consumption of firewood is significant in Karnak (2.3) in comparison with the two other villages because of the lack of other domestic energy sources (Table 6) on the other hand the daily consumption per inhabitant is high in Dourbali $(147795.3 \mathrm{~kg})$.

Table 5. Quantity of firewood produced, sold and consumed by each village (steres/year).

\begin{tabular}{llll|}
\hline Villages & Production & Consumption & Exportation \\
\hline Bodro & 246894 & 53945.2845 & 192948.72 \\
Karnak & 119100 & 16096.5 & 103003.5 \\
Dourbali & 65892 & 10913.5 & 54978.5 \\
Mean & 143962.00 & 26985.09 & 116976.91 \\
\hline
\end{tabular}

Typology of firewood consumers out of households

Among the firewood consumers out of households, are classified in order of importance: butchers (90\%) and the restaurants (86\%) (Fig. 4). The firewood remains the main energy source for the different people using it.

\section{Firewood commercialization circuit}

There are two types of firewood commercialization circuit: the short and the long circuits. The short circuit does not have an intermediary and product goes directly from the lumberjack to the consumer. As for the long circuit, it has two or more than two intermediary (Fig. 5).

Table 6. Firewood consumption $(\mathrm{kg})$ in the households per inhabitant and per day $(\mathrm{C} / \mathrm{P} / \mathrm{Jr})$, person per month $(\mathrm{C} / \mathrm{P} / \mathrm{m})$, per inhabitant per year (C/inh/y).

\begin{tabular}{lllll}
\hline Village & $\mathbf{C} / \mathbf{p} / \mathbf{j r}$ & $\mathbf{C} / \mathbf{p} / \mathbf{m}$ & $\mathbf{C} / \mathbf{h a b} / \mathbf{j r}$ & $\mathbf{C} / \mathbf{h a b} / \mathbf{a n}$ \\
\hline Dourbali & $1.9^{\mathrm{b}}$ & 57 & $147795.3^{\mathrm{a}}$ & $53945285^{\mathrm{a}}$ \\
Bodro & $2.1^{\mathrm{a}}$ & 63 & $44100^{\mathrm{b}}$ & $16096500^{\mathrm{b}}$ \\
Karnak & $2.3^{\mathrm{a}}$ & 69 & $29900^{\mathrm{c}}$ & $10913500^{\mathrm{c}}$ \\
Mean & 2.1 & 63 & 73931.77 & 26985094.8 \\
\hline
\end{tabular}

Assigned figures of the same letters are not significant up to 0.05 threshold.

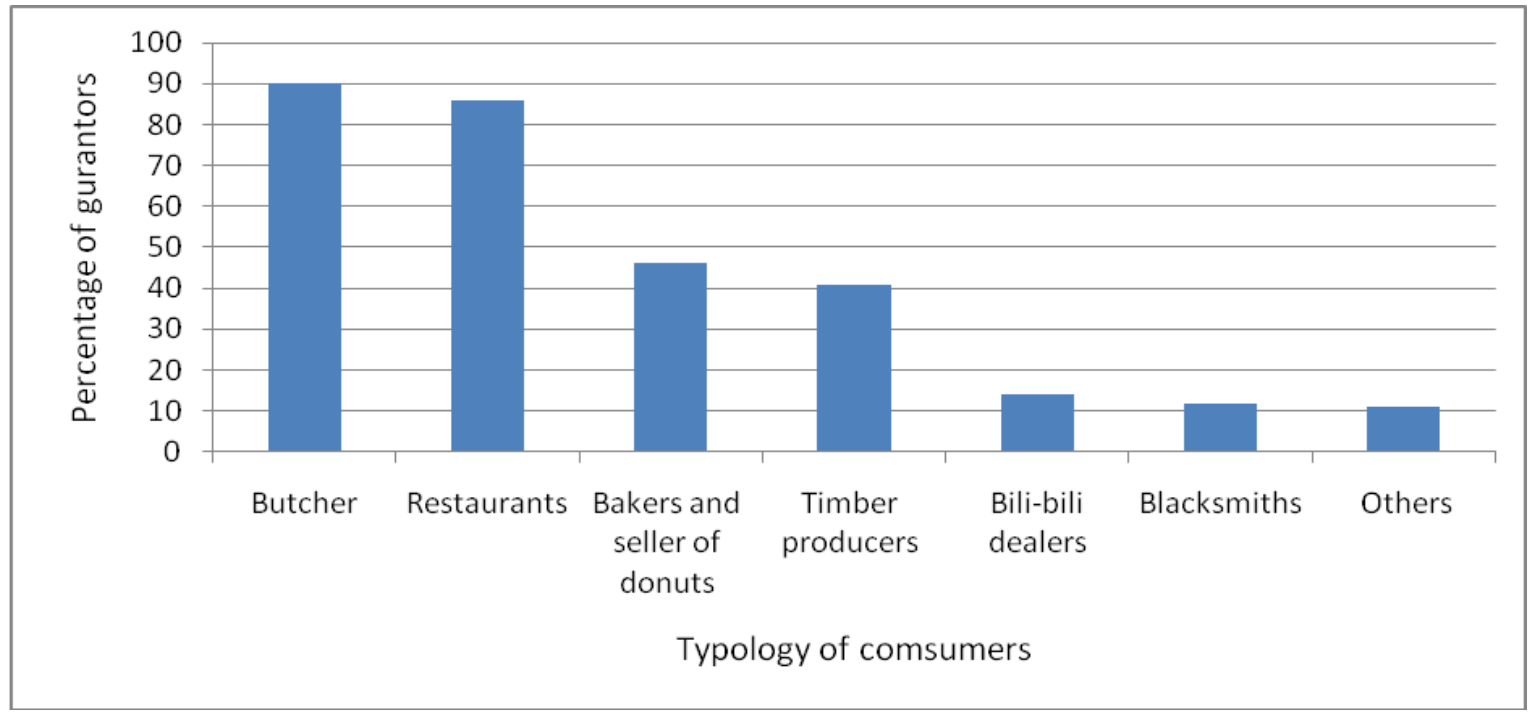

Fig. 4 : Consumer typology of firewood management. 


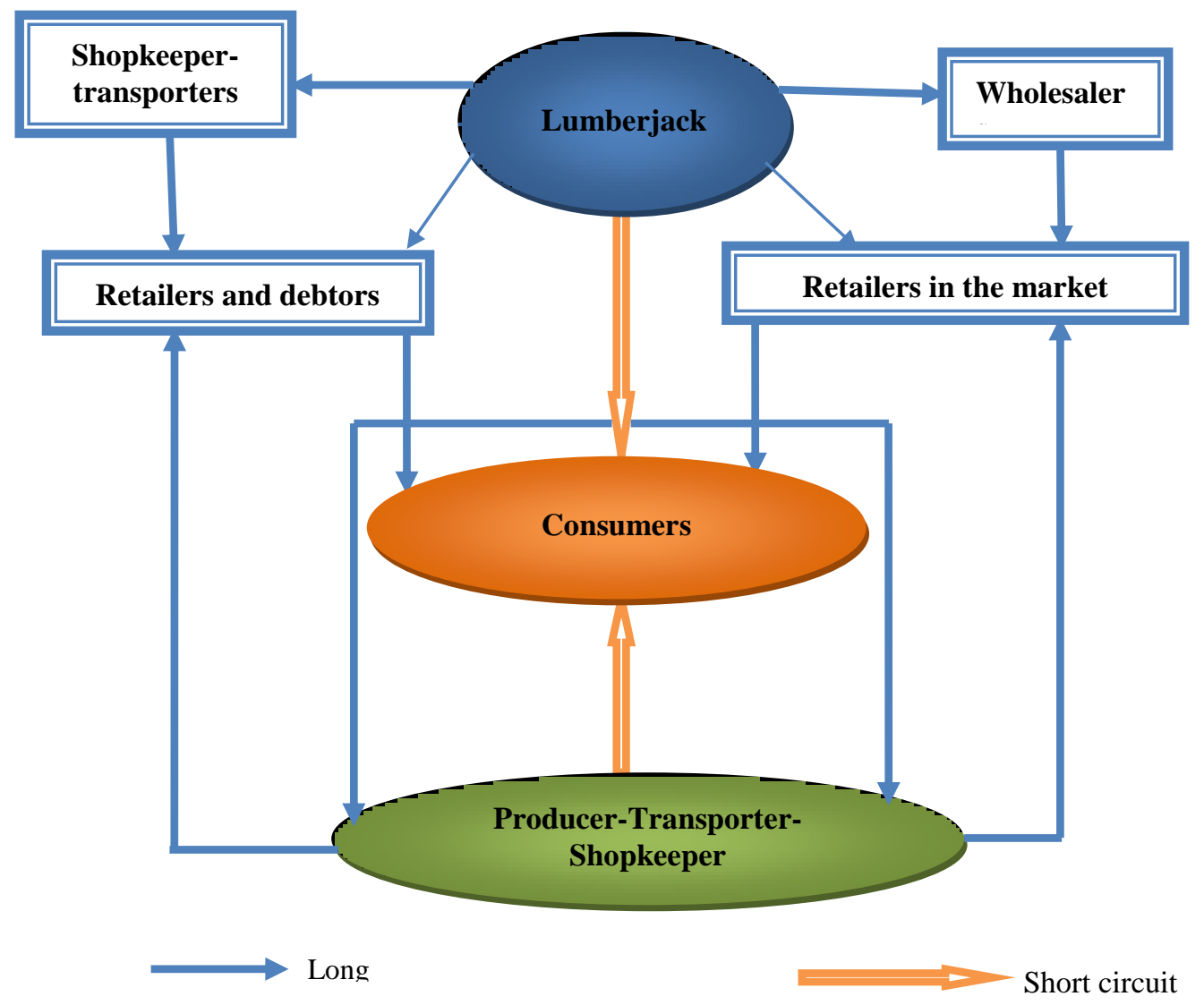

Fig. 5: Firewood commercialization circuit.

Firewood price variation in the area of research in Ndjamena town

The firewood price variation varies according to some years and the demographic pressure combined with the high demand (Table 7). From 2000 to 2013, the firewood price per stem, evaluated at (about $2 \mathrm{~m}$ long to $60 \mathrm{~cm}$ of circumference) fluctuate from 50 FCFA to 250 FCFA in rural areas, with a profit margin of 200 FCFA. In Ndjamena, the price fluctuates from 100FCFA-125FCFA to 750FCFA-1.500FCFA; with a profit margin of 650 FCFA to 1.375 FCA. For a truck of 7 tons, the price of firewood fluctuates form 15.000 CFA - 20.000 FCFA to 65.000 FCFA - 80.000 FCFA in rural areas with a profit margin of 50.000 FCFA to 60.000 FCFA. The price of an articulated lorry carrying firewood rises from 45.000 FCFA - 50.000 FCFA to 350.000 FCFA - 400.000 FCFA in rural areas with a profit margin ranging of 305,000 FCFA to 350.000 FCFA. This result can be justified by the high demand of firewood by the population and the demographic pressure of these latest years.

Table 7. The evolution of firewood prices in the rural areas and Ndjamena town according to the years.

\begin{tabular}{llll}
\hline Years & Quantity & Rural areas prices (FCFA) & N'Djamena town prices (FCFA) \\
\hline 2000 & 1 Stem & 50 & 100 to 125 \\
& 17 tons truck & 15000 to 20000 & 28000 to 45000 \\
2006 & 1 Articulated lorry & 45000 to 50000 & 65000 to 72000 \\
& 1 Stem & 125 to 175 & 250 to 325 \\
& 17 tons truck & 25000 to 35000 & 40000 to 55000 \\
2013 & 1 Articulated lorry & 110000 to 125000 & 20000 to 240000 \\
& 1 Stem & 250 to 350 & 750 to 1500 \\
& 17 tons truck & 65000 to 80000 & 90000 to 150000 \\
& 1 Articulated lorry & 200000 to 250000 & 350000 to 400000 \\
\hline
\end{tabular}




\section{Beneficiary approach firewood exploitation}

The average income of firewood exploitation depends on the types of actors involved. The wholesalers are the base beneficiaries (88 $33.33 \mathrm{FCFA} /$ day or 2649 99.9 FCFA/month of the firewood course of study compared to those of lumberjacks (38 33.33 FCFA/day or 114999.9 FCFA/month who only earn around the $1 / 3$ of the latest (Table 8). This result is a testimony that the lumberjacks do not really benefit from their activities; hence not improving their living conditions.

Table 8. Financial income by actors in the firewood (FCFA).

\begin{tabular}{llll}
\hline Actors & Income by day & income per month & Income per year \\
\hline Wholesalers & 8833.33 & 264999.9 & 3179998.8 \\
Shop keepers-transporters & 8500 & 255000 & 3060000 \\
Shop keepers-producers & 6500 & 195000 & 2340000 \\
Shop keepers-producers -transporters & 6333.33 & 189999.9 & 2279998.8 \\
Market retalers & 4000 & 120000 & 1440000 \\
Lumberjack/producers & 3833.33 & 114999.9 & 1379998.8 \\
Retailers and debtors & 1250 & 37500 & 450000 \\
\hline
\end{tabular}

\section{Distributions of firewood sale income}

For most of the actors we carried out an investigation into, the firewood financial incomes are used in family basic necessity needs, particular foot (44\%) and agriculture (20\%) (Fig. 6).

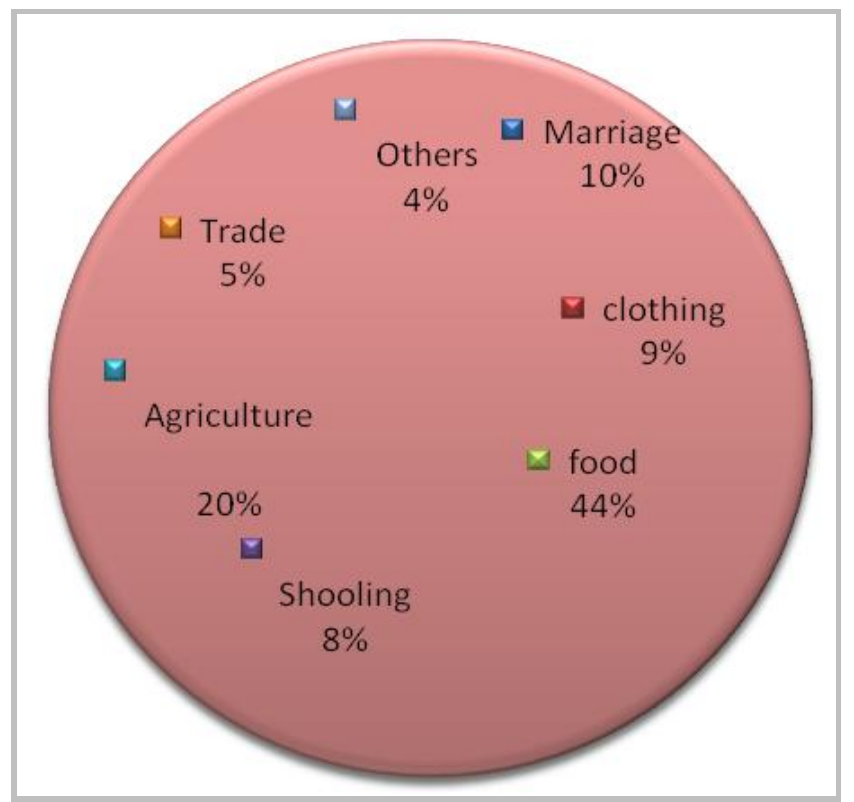

Fig. 6: Benefit usage (\%).

\section{Problems related to firewood exploitation}

The first problem related to firewood exploitation is the remoteness of some resources $(86.33 \pm 3.68)$. It is

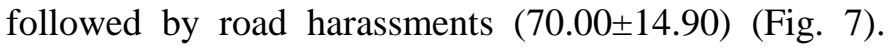
This result explains the drop in the vegetation and the actor's lack of organization in groups or association aiming at facing road challenges.

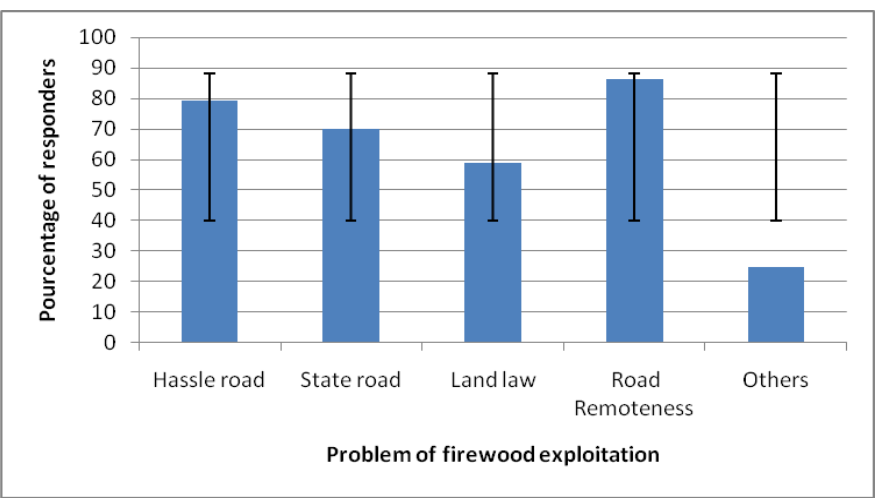

Fig. 7: Problems related to firewood exploitation.

The impact of firewood exploitation on human and plant health

The exploitation of firewood without any sanitary precaution exposes the population to diseases such as eye problem $(31 \%)$ and the respiratory problems $(20 \%)$, blood stain (18\%) burn suffering (17\%) and flu (14\%) (Fig. 7). These diseases are due to the presence of toxic substances found in the wood. Composition and the use of fresh wood burnt later. The health of wood happens with the cutting and the graze of the wood in the three villages. The wood cutting aims at furnishing domestic energy and the crazing helps in craft industries and traditional medicine (Fig. 8).

The impact of firewood exploitation on the distribution of the ligneous stratum according to the $<10 \mathrm{~cm}$ and $\geq 10 \mathrm{~cm}$ circumference

The ligneous of $<10 \mathrm{~cm}$ circumference shows an important density in Karnak (180 subjects/ha) in the shrubs savannah and (136 subjects/ha) in the forestry 
gallery of Bodro. The less significant density is listed in the Dourbali shrubs savannahs (88 subjects/ha) and in Bodro (94 subjects/ha) (Fig. 9a).

The vegetation show a "U" form according to the formation of vegetation. The density of vegetal population is higher at the level of savannahs in the three villages. It is poor in the shrub savannahs and sparse forest. It is slightly more important in forestry galleries than the three villages. For the ligneous species with $\geq 10$ $\mathrm{cm}$ circumference the woody densities are respectively important in shrub savannahs (20 subjects/ha) and forestry galleries (19 subjects/ha) in the Bodro villages. The less important of the woody species were listed in shrub in the shrubs savannah ( 9 subjects/ha) and at the level of forestry gallery (10 subjects/ha) both found in the Dourbali village (Fig. 9b). Broadly speaking, the densities of woody species with $\geq 10 \mathrm{~cm}$ of circumference remain poor compared with the woody species with $<10 \mathrm{~cm}$ circumference. In fact, high trees were cut down to be used as firewood species. It is only the stumps which are cut to be used as firewood, and this explains the high density of trees with $<10 \mathrm{~cm}$ circumference.

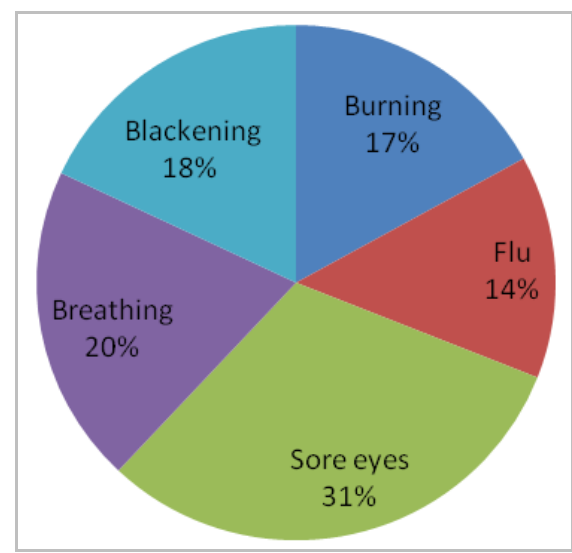

(a)

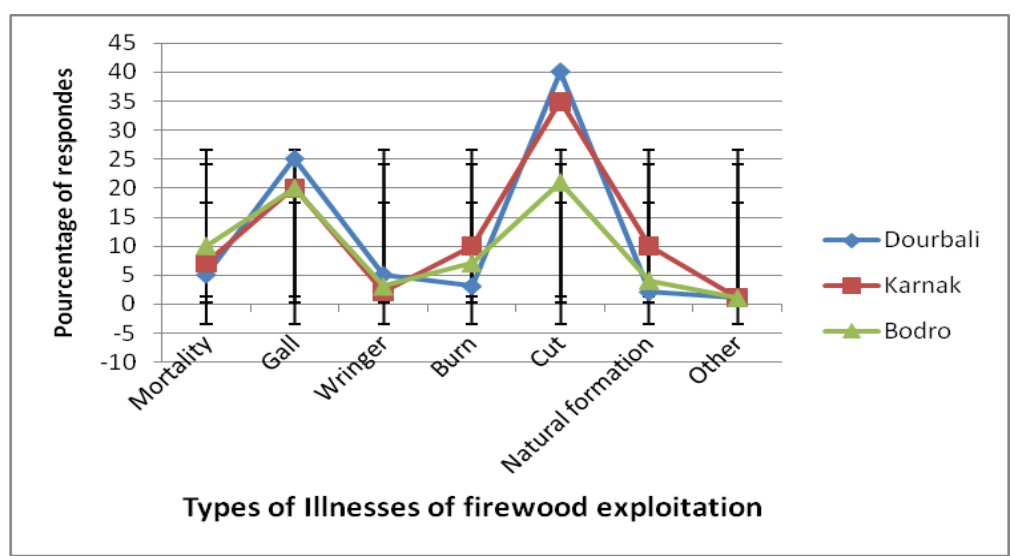

(b)

Fig. 8: Illnesses related to firewood exploitation and vegetation health. (a) Diseases related to firewood exploitation for human; (b) Vegetation health indication.

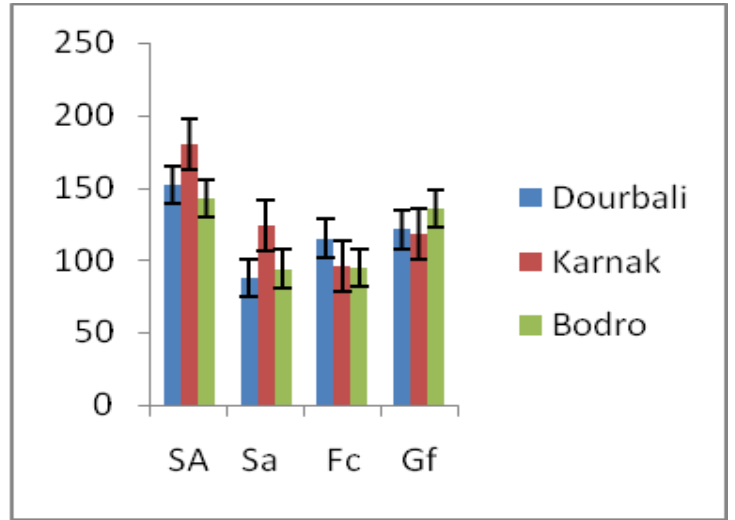

Fig. 9a: Distribution of the ligneous species density with< $10 \mathrm{~cm}$ circumference.

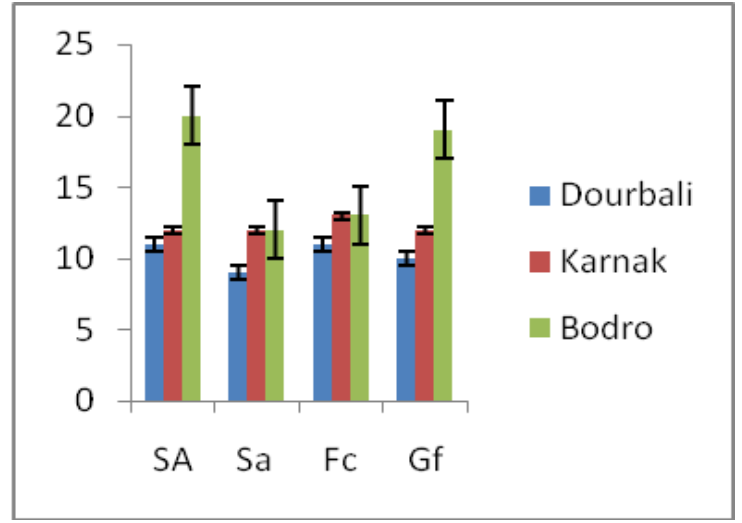

Fig. 9b: Distribution of the ligneous species density with $\geq 10 \mathrm{~cm}$ circumference.
The impacts of firewood exploitation on the diameter distribution, the diameter and height of the tassel and the diameter of the ligneous tassel with $<100 \mathrm{~cm}$ circumference according to the villages

Table 9 shows that in all the three villages, there is a high and significant difference $0.0000<0.001$ in accordance with the diameters. The diameter of trees with chest height $(28.54 \pm 6.5 \mathrm{~cm} / \mathrm{ha})$ is more consider in Bodro village. This shows that the vegetation is better preserved and less exposed to the firewood phenomenon. Large trees are protected compared with the Dourbali village where trees with chest height $(9.13 \pm 1.7 \mathrm{~cm} / \mathrm{ha})$ is very poor. 
The height and diameter of the bunch is significantly difference in the Dourbali village $(\mathrm{P}=0.05)$. This result justifies the anthropic pressure in the village. In Karnak and the Bodro there are not significant differences $(p=0.05)$ between the trees height and the bunch diameter.

Table 9. Diameter, height, and diameter of the tassel in relation with the villages.

\begin{tabular}{llll}
\hline Villages & Diameter $(\mathbf{c m} / \mathbf{h a})$ & Height $(\mathbf{m})$ & Bunch $(\mathbf{m})$ \\
\hline Dourbali & $9.13 \pm 1.7^{\mathbf{a}}$ & $2.25 \pm 0.4^{\mathbf{a}}$ & $2.69 \pm 0.5^{\mathbf{a}}$ \\
Karnak & $19.13 \pm 5.6^{\mathbf{b}}$ & $4.09 \pm 1.4^{\mathbf{b}}$ & $5.05 \pm 2.4^{\mathbf{b}}$ \\
Bodro & $28.54 \pm 6.5^{\mathbf{c}}$ & $4.42 \pm 1.4^{\mathbf{b}}$ & $4.59 \pm 1.7^{\mathbf{b}}$ \\
\hline
\end{tabular}

Assigned figures of the same letters are not significant up to 0.05 threshold.

The impacts of the firewood exploitation on the distribution in terms of diameter of woody species with $\geq 10 \mathrm{~cm}$ circumference of the formations vegetation

The ANOVA put together with the Duncan test, shows a significant difference of the diameters $(10.22 \pm 4.9)$, height $(2.75 \pm 0.85)$ and bunch $(3.07 \pm 1.3)$ of the trees in shrub savannahs. This result explains the height forest destructor rate in the formation vegetation (Table 10). Elsewhere, there is no significant difference between the diameters, the height and the bunch diameter for planted tree savannahs, sparse forest and the forestry galleries. This result shows that these three formations of vegetation are less risky for firewood exploitation.

Table 10. Diameter, height and tassel in relation with the formation of vegetation.

\begin{tabular}{llll}
\hline Formations of vegetation & Diameter & Height & Tassel \\
\hline Planted tree savannah & $18.94 \pm 14^{\mathrm{a}}$ & $5.34 \pm 3.6^{\mathrm{b}}$ & $4.8 \pm 2.4^{\mathrm{a}}$ \\
Shrub savannah & $10.22 \pm 4.9^{\mathrm{b}}$ & $2.75 \pm 0.85^{\mathrm{a}}$ & $3.07 \pm 1.3^{\mathrm{b}}$ \\
Sparse forest & $19.04 \pm 13.4^{\mathrm{a}}$ & $5.6 \pm 3.6^{\mathrm{b}}$ & $4.94 \pm 2.3^{\mathrm{a}}$ \\
Forestry gallery & $20.6 \pm 18^{\mathrm{a}}$ & $5.7 \pm 3.7^{\mathrm{b}}$ & $5.64 \pm 4^{\mathrm{a}}$ \\
\hline
\end{tabular}

Figures assigned the same letters are not significant with the 0.05 threshold.

The impact of the firewood exploitation on the DBH $(\mathrm{cm})$, diameter $(\mathrm{cm})$, height $(\mathrm{m})$ and the bunch diameter of woody species with $\geq \mathbf{1 0}$ circumference

The Ficus gnacalocapa (88cm), Sterculia setigera (47 $\mathrm{cm})$, Bombax costatum $(37.5 \mathrm{~cm})$, Cynometra vogelii $(31$ $\mathrm{cm})$, Diospyros mepiliforis $(30.88 \mathrm{~cm})$ species have the most important DBH in accordance with other species. On the other hand the Grewia bicolor, Ceiba pentandra, Capparis puberula have respectively $4.2 \mathrm{~cm} ; 4 \mathrm{~cm} ; 3.25$ $\mathrm{cm}$ DBH (Table 11). The Principal Component Analysis $(\mathrm{ACP})$ of the DBH $(\mathrm{cm})$, diameter $(\mathrm{cm})$, height $(\mathrm{m})$ and the bunch diameter of the species with $\geq 10 \mathrm{~cm}$ circumference shows that there is a high correlation rate (Pearson (n)) between the trees height and the bunch diameter of the trees $(\mathrm{R}=0,71 ; \mathrm{P}=0.05)$. This shows that, when the trees have a great height, the bunch diameter increases. For that purpose the leaf recovery is important. There is an absolute correlation $(\mathrm{R}=1 ; p=0.05)$ between the DHP and the average diameter of the trees (Fig. 10). This instance correlation between the four parameters is materialized by a height concentration of some species at the level of horizontal axis F1 of $81.20 \%$. But when following vertical axis of the ordinates, there is a low correlation between the species $(\mathrm{F} 2=11.69 \%)$. According to the Bitplot (axis F1 and F2) there are more than
$92.89 \%$ of correlation between the species. The species which are highly correlated constitute dense clouds at the level of the compensation point of the horizontal axis and the ordinates. However the Ficus gnatocephala form a separate group with the reason of their most important dendrometric parameters. This species is isolated from the others and form itself a group. Besides this species the Bombax costatum, Borassus aethiopum, Combretum molle, Entada africana, Cynometra vogelii, Sterculia setigera, Diospyros mespiliformis and Terminalia macroptera, constitute another group.

The hierarchical ascendant classification (HAC) shows that the species are distributed in the space in a uniform way. Following plans F1× F2, four dense clouds points are differentiated. Cloud 1 form class 1 with 22 species; clouds 2 form class 2 with 42 species; cloud 3 form class 3 with 8 species and cloud 4 form class 4 with one species (Fig. 11). Those four classes can be classified as follows.

Class1: it groups together $30.14 \%$ species. Within this class the subjects have high esteem in firewood usage and their regeneration is difficult with constant tree cutting. This is the specificity of the Dourbali village with the following species: Acacia albida; Acacia 
radiana; Acacia senegal; Acacia seyal; Andansonia digitata; Anogeissus leocarpus; Capparis fasucularis; Combretum lecardii; Combretum nigricans; Hyhaena thebaica; Mitragyna inermis; Parkia biglobosa; Piliostigma reticulatum; Piliostigma thonningii; Sclerocaria birrea; Senna sp.; Terminalia glaucescens; Vitalaria paradoxa; Vitex doniana; Ziziphus spina christis.

Class 2: has the greatest number of species $(57.53 \%)$. This category of species is also threatened by anthropic actions. The observation was also done in Dourbali village on the following species.

Acacia gourmaensis; Acacia nilotica; Acacia polyacantha; Acacia senegal; Acacia sp.; Albizia zigya; Allophyllus africanus;Azadirachta indica; Balanites aegyptiaca; boswellia dalzielii; Boswellia occidentalis; Bridelia ferruginia; Cadaba farinosa; Capparis puberula; Capparis tomentosa; Combretum fragrans; Combretum glutinosum; Combretum micrantum;Combretum mollis; Dalberzia melanoxylon; Dalberzia lata; Daniellia oliveri; Guaedenia aquala; Grewia bicolor; Grewia flavenscens; Faiderbia albida; Ceiba pentandra; Prosopis africana; Crataeva adanonii; Lanea barteri; Maerua crassifolia; Maytenus senegalensis; Mimosa sp; Phylanthus sp.; Senna sieberiana; Senna spectabilis; Strychnos spinosa; Tamarindus indica; Terminalia mollis; Terminalia sp.; Ximenia americana; Ziziphus mauritiana.

Class3: it affects $10.96 \%$ of species. This category of species is under the thread of anthropic action and easily fits in the area (Fig. 11).

Table11. The DBH $(\mathrm{cm})$, the diameter $(\mathrm{cm})$, the height $\mathrm{m}$ and the bunch diameter of species with $\geq 10 \mathrm{~cm}$ circumference.

\begin{tabular}{|c|c|c|c|c|c|c|c|c|c|}
\hline Scientific names & $\begin{array}{l}\text { DBH } \\
(\mathrm{cm})\end{array}$ & $\begin{array}{l}\text { Diam } \\
(\mathbf{c m})\end{array}$ & $\begin{array}{l}\text { Height } \\
\text { (m) }\end{array}$ & $\begin{array}{l}\text { Bunch } \\
\operatorname{diam}(m)\end{array}$ & Scientific names & $\begin{array}{l}\text { DBH } \\
(\mathrm{cm})\end{array}$ & $\begin{array}{l}\text { Diam } \\
(\mathbf{c m})\end{array}$ & $\begin{array}{l}\text { Height } \\
\text { (m) }\end{array}$ & $\begin{array}{l}\text { Bunch } \\
\text { diam } \\
\text { (m) }\end{array}$ \\
\hline Acacia albida & 16.63 & 21.18 & 10.5 & 6.5 & Gardenia aquala & 7 & 8.92 & 2 & 2.5 \\
\hline Acacia gourmaensis & 4.3 & 5.48 & 1.8 & 2 & Grewia bicolor & 4.2 & 5.35 & 2 & 2 \\
\hline Acacia nilotica & 7.88 & 10.03 & 6.5 & 4 & Grewia flavescens & 7.45 & 9.49 & 2 & 3 \\
\hline Acacia polyacantha & 10.18 & 12.96 & 3.5 & 4 & Hyhaena thebaica & 18.5 & 23.57 & 14.6 & 8 \\
\hline Acacia radiana & 16.13 & 20.54 & 7 & 8 & Faiderbia albida & 10.28 & 13.09 & 4.6 & 4.5 \\
\hline Acacia senegal & 16.42 & 20.91 & 6.53 & 6.67 & Ceiba pentandra & 4 & 5.1 & 2 & 2.8 \\
\hline Acacia sieberiana & 20.58 & 26.21 & 6.6 & 8 & Crataeva adanonii & 9.7 & 12.36 & 2.6 & 4.6 \\
\hline Acacia $\mathrm{sp}$ & 10.18 & 12.96 & 10 & 5 & Sterculiana setigera & 47 & 59.87 & 11 & 11.5 \\
\hline Adansonia digitata & 16.25 & 20.7 & 6 & 5 & Diospyros mespiliformis & 30.88 & 39.33 & 11 & 10.5 \\
\hline Albizia zigya & 7 & 8.92 & 2 & 5 & Lannea barteri & 12.25 & 15.61 & 3.6 & 3 \\
\hline Allophilus africanus & 10.75 & 13.69 & 4 & 4 & Maerua crassifolia & 10 & 12.74 & 3.5 & 6 \\
\hline Anorgeissus leocarpus & 19.5 & 24.84 & 6.2 & 7 & Maytenus senegalensis & 9.125 & 11.62 & 3.3 & 4 \\
\hline Boswellia dalzielii & 9.05 & 11.53 & 2.6 & 2 & Piliostigma reticulatum & 24.13 & 30.73 & 4.5 & 4.5 \\
\hline Boswesllia occidentalis & 12.25 & 15.61 & 3 & 3 & Piliostigma thonningii & 16.5 & 21.02 & 12.6 & 8 \\
\hline Bridelia ferruginia & 10.7 & 13.63 & 6.5 & 4.5 & Sclerocarya birrea & 15 & 19.11 & 3 & 6 \\
\hline Cadaba farinosa & 5.75 & 7.32 & 3.4 & 3 & Senna sieberiana & 9.75 & 12.42 & 7 & 3 \\
\hline Capparis fascicularis & 22.33 & 28.44 & 10.5 & 6 & Senna sp. & 20 & 25.48 & 7 & 5.5 \\
\hline Capparis puberula & 3.25 & 4.14 & 1.7 & 2 & Senna spectabilis & 12.23 & 15.57 & 5 & 6.5 \\
\hline Capparis tomentosa & 4.425 & 5.64 & 2 & 3 & Strychnos spinosa & 12.55 & 15.99 & 2.7 & 3 \\
\hline Combretum lecardii & 23.25 & 29.62 & 7.5 & 6 & Tamarindus indica & 7.1 & 9.04 & 4 & 3.8 \\
\hline Combretum fragans & 10.85 & 13.82 & 8 & 5 & Terminalia albida & 20 & 25.48 & 5.5 & 4.5 \\
\hline Combretum glutinosum & 11.93 & 15.19 & 9 & 3.9 & Terminalia glaucescens & 20.35 & 25.92 & 6 & 5.5 \\
\hline Combretum micrantum & 9.43 & 12.01 & 2.9 & 3.8 & Terminalia macroptera & 25.5 & 32.48 & 11.5 & 6.5 \\
\hline Combretum mollis & 7.25 & 9.24 & 2.8 & 3 & Terminalia mollis & 11.65 & 14.84 & 7.6 & 5 \\
\hline
\end{tabular}




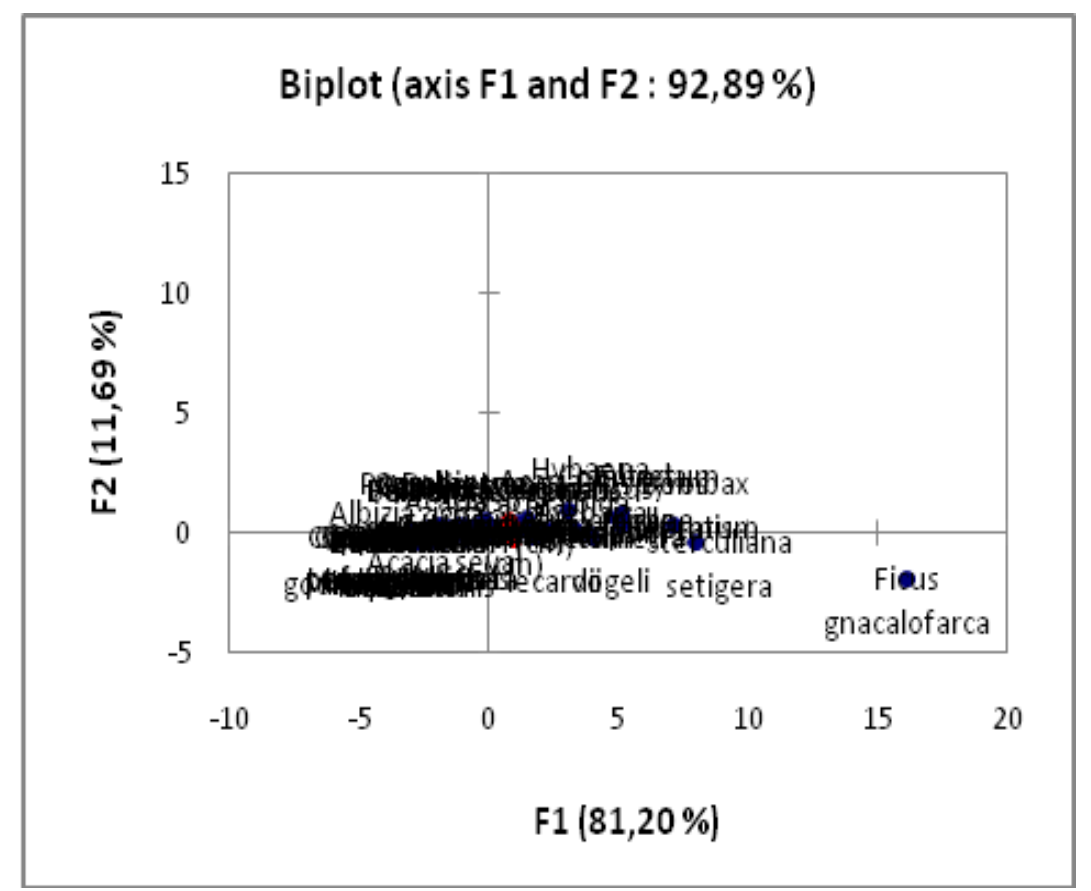

Fig. 10: Principal Component Analysis (PCA) of DBH $(\mathrm{cm})$, diameter $(\mathrm{cm})$, height $(\mathrm{m})$ and the bunch diameter of species with $\geq 10 \mathrm{cmcircumference}$.
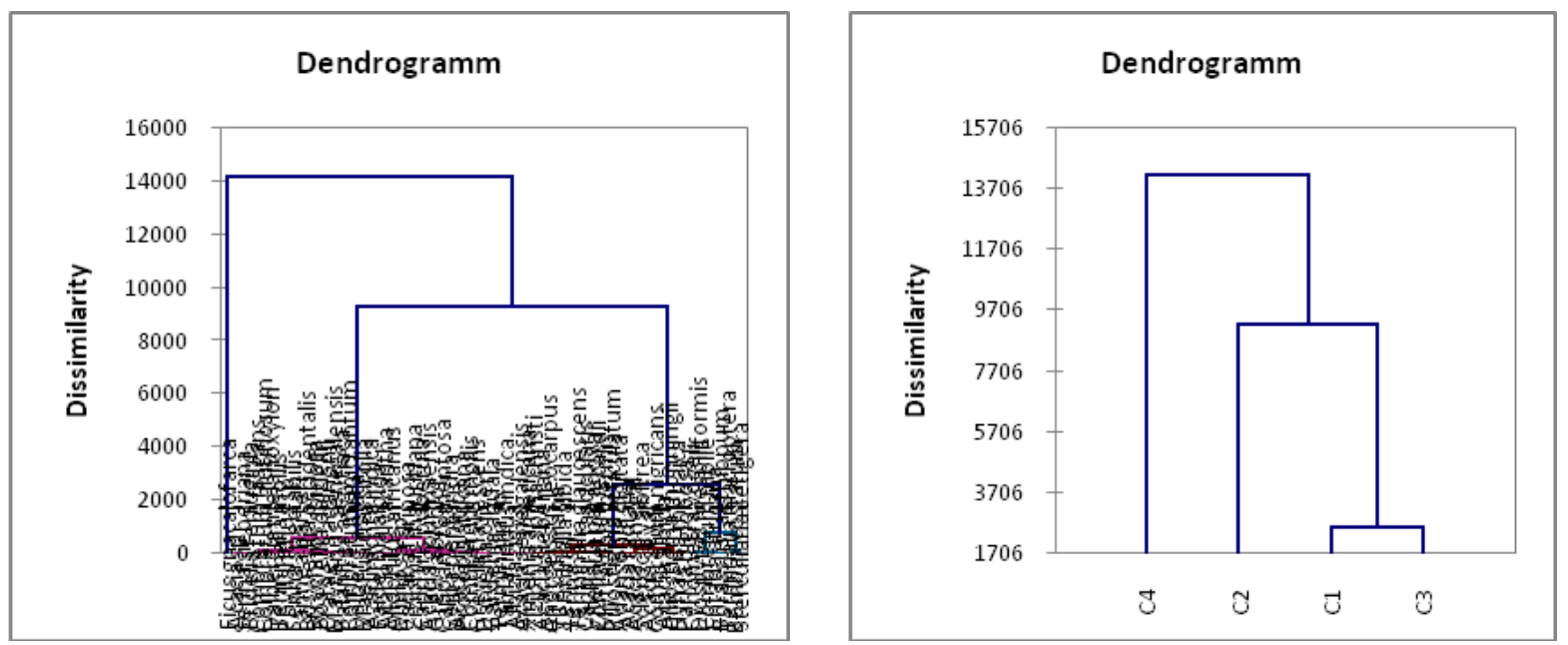

Fig. 11: Dendogram of the DBH $(\mathrm{cm})$, the diameter $(\mathrm{cm})$, the height $(\mathrm{m})$ and the bunch diameter of species with $\geq 10 \mathrm{~cm}$ circumference.

\section{Factorial analysis of the correspondences (FAC)}

Table 12 shows the weight, the distances and the existing inertia between the four dendrometric parameters. The most significant weight is found at the level of the 0.33 diameter distance against the most significant which is found at the level of the bunch diameter and finally the inertia is located at the level of the tree height.

Table 12. Weights distances and inertias between the dendrometric parameters.

\begin{tabular}{llllll}
\hline Parameters & Relative weight & Distance & Distance $^{2}$ & Inertia & Relative inertia \\
\hline DBH $(\mathrm{cm})$ & 0.331 & 0.099 & 0.010 & 0.003 & 0.077 \\
Diam $(\mathrm{cm})$ & 0.421 & 0.099 & 0.010 & 0.004 & 0.098 \\
Height $(\mathrm{m})$ & 0.135 & 0.360 & 0.129 & 0.017 & 0.413 \\
Diam of the bunch $(\mathrm{cm})$ & 0.113 & 0.393 & 0.154 & 0.017 & 0.411 \\
\hline
\end{tabular}


The impacts of firewood exploitation on the specific richness in the floristic diversity

Among the woody species with $<10 \mathrm{~cm}$ circumferences, the Shannon diversity indexes and their reverse are more important in sparse forests (ISH=1.91) and ( $\mathrm{In}=0.52)$ the Pielou specific resources and Equitability are the most considerate ones at the level of forest galleries $(\mathrm{Rs}=21$; $\mathrm{EQ}=1.18$ (Table 13 ) with woody specifies $\geq 10 \mathrm{~cm}$ on the other hand the Shannon diversity indexes and their reverse are the most represented species at the level of the forest galleries (ISH=2.13) and $(\mathrm{In}=0.47)$ the Pielou specific resources and Equitability are the most visible ones at the level of sparse forest ( $\mathrm{Rs}=46$ and $\mathrm{EQ}=0.087$ ). In fact the poor specific resources of the sparse forests (9) and Shrubs savannah (14) at the level of woody species with $<10 \mathrm{~cm}$ are the result of anthropic pressure Knocked down with an impact on young trees for firewood. And this is the result of the poor density of the species in those two formations of vegetation.

Table 13.The validity of specific resources (Rs) the Shannon index (ISH) its reverse (Re) and the Pielou Equitability (EQ) of the ligneous species with $<10 \mathrm{~cm}$ and $\geq 10 \mathrm{~cm}$.

\begin{tabular}{lllllllll}
\hline Parameter & SA & \multicolumn{3}{c}{ Sa } & Fc & Gf & \\
\hline Cir & $\geq 10 \mathrm{~cm}$ & $<10 \mathrm{~cm}$ & $\geq 10 \mathrm{~cm}$ & $<10 \mathrm{~cm}$ & $\geq 10 \mathrm{~cm}$ & $<10 \mathrm{~cm}$ & $\geq 10 \mathrm{~cm}$ & $<10 \mathrm{~cm}$ \\
Rs & 34 & 18 & 34 & 14 & 46 & 9 & 39 & 21 \\
ISH & 1.53 & 1.86 & 1.53 & 1.55 & 1.91 & 1.19 & 1.68 & 2.13 \\
In & 0.65 & 0.54 & 0.65 & 0.65 & 0.52 & 0.84 & 0.59 & 0.47 \\
EQ & 0.7 & 1.03 & 0.7 & 0.86 & 0.87 & 0.66 & 0.77 & 1.18 \\
\hline
\end{tabular}

The impact of firewood exploitation on the frequency, the dominance, the relative density and the important value of woody species with $<10 \mathrm{~cm}$ circumference

The species showing a relative density of (7.59\%), a relative frequency of $(7.78 \%)$, a relative dominance of (9.29\%) and the important value (24.66\%) high are Capparis tomentosa and Acacia senegal (Table 14). Those two species fit all the ecological environments. They swiftly regenerate. The other species: the Cadaba farinosa, the Daniellia oliveri and Parkia biglobosa on the other hand are the mostly poor representative species in the different formation of vegetation (Dre=0.63\%; Fre $=0.522 \%$; $\mathrm{DRe}=0.10 \%$ and $\mathrm{IV}=0.26 \%$ ). Those three species are threatened of extinction because of the high firewood exploitation rate and non woody forestry product.

Table 14. Relative density, relative frequency, relative dominance and important value of some species with $<10 \mathrm{~cm}$ circumference at the level of all research area (\%).

\begin{tabular}{|c|c|c|c|c|c|c|c|c|c|}
\hline Scientific names & Dre & Fre & Dre & IV & Scientific names & Dre & Fre & Dre & IV \\
\hline Capparis tomentosa & 7.59 & 7.78 & 9.29 & 24.66 & Anogeissus leiocarpus & 1.90 & 1.56 & 0.87 & 4.33 \\
\hline Acacia sp. & 7.59 & 7.78 & 9.29 & 24.66 & Combretum fragrans & 1.27 & 1.04 & 0.39 & 2.7 \\
\hline Acacia nilotica & 6.96 & 7.26 & 8.61 & 22.83 & Bridellia ferruginia & 1.27 & 1.04 & 0.39 & 2.7 \\
\hline Acacia seyal & 6.96 & 7.26 & 8.61 & 22.83 & Grewia sp. & 0.63 & 0.67 & 0.39 & 1.69 \\
\hline Mimosa sp. & 6.33 & 6.74 & 8.13 & 21.2 & Acacia sieberiana & 0.63 & 0.52 & 0.10 & 1.25 \\
\hline Mitragyna inermis & 5.70 & 5.51 & 7.83 & 19.04 & Acacia sieberiana & 0.63 & 0.52 & 0.10 & 1.25 \\
\hline Acacia gourmaensis & 5.70 & 5.98 & 7.45 & 19.13 & Dalbergia melanoxylon & 0.63 & 0.52 & 0.10 & 1.25 \\
\hline Piliostigma reticulatum & 6.33 & 6.36 & 5.90 & 18.59 & Ximenia americana & 0.63 & 0.52 & 0.10 & 1.25 \\
\hline Senna spp. & 3.80 & 3.71 & 6.58 & 14.09 & Entada africana & 0.63 & 0.52 & 0.10 & 1.25 \\
\hline Balanites aegyptiaca & 5.70 & 5.84 & 5.22 & 16.76 & Vitellaria paradoxa & 0.63 & 0.52 & 0.10 & 1.25 \\
\hline Ziziphu smauritiana & 5.70 & 5.93 & 3.97 & 15.6 & Sclerocarya birrea & 0.63 & 0.52 & 0.10 & 1.25 \\
\hline Combretum lecardii & 3.80 & 3.89 & 2.32 & 10.01 & Cadaba farinosa & 0.63 & 0.52 & 0.10 & 1.25 \\
\hline Crataeva adansonii & 3.16 & 3.55 & 1.64 & 8.35 & Daniellia oliveri & 0.63 & 0.52 & 0.10 & 1.25 \\
\hline Terminalia $\mathrm{sp}$ & 2.53 & 2.38 & 1.93 & 6.84 & Parkia biglobosa & 0.63 & 0.52 & 0.10 & 1.25 \\
\hline Hyphaena thebaïca & 2.53 & 2.23 & 1.26 & 6.02 & Total & 79.75 & 81.68 & 87.35 & 248.78 \\
\hline
\end{tabular}

The impact of firewood exploitation on the frequency the relative dominance, the relative density and important Value of woody species $\geq 10 \mathrm{~cm}$ of circumference

The species showing the most significant relative densities (Red) are the Acacia hockii and Balanites aegyptica witch represent $4.62 \%$ rate. Globally, all the species presented on Table 15 are accidental species found in the sites knowing that the relative frequency indexes are less than $20 \%$. From this analysis, one can say that the formations of vegetation are not considerable with the rapid destruction of the forests. Many of them are threatened of extinction. Among them, we can talk about the Lannea barteri, Terminalia acida and Vitex doniana which represent $0.23 \%$ of rate and are more noteworthy. The relative density of the species is dominated by the Acacia hockii and Balanites aegyptiaca which represent $(4.93 \%)$. The same species show an Important Value which is higher, that is $5.66 \%$. 
Table 15. Relative density, relative frequency relative dominance and Important Value of species with $<10 \mathrm{~cm}$ circumference in all the areas of research.

\begin{tabular}{|c|c|c|c|c|c|c|c|c|c|}
\hline Scientific names & Dre & Fre & DRe & IV & Scientific names & Dre & Fre & Dre & IV \\
\hline Acacia hockii & 4.62 & 4.9 & 6.5 & 16.05 & Senna spectabilis & 1.15 & 0.83 & 1.22 & 3.2 \\
\hline Sclerocaryabirrea & 3.85 & 4 & 4.88 & 12.75 & Hyphaena thebaïca & 1.15 & 1.05 & 0.68 & 2.88 \\
\hline Acacia albida & 3.85 & 4.2 & 4.61 & 12.66 & Maerua crassifolia & 0.77 & 0.55 & 0.54 & 1.86 \\
\hline Acacia senegal & 3.85 & 4.2 & 4.61 & 12.66 & Parkia biglobosa & 0.77 & 0.55 & 0.54 & 1.86 \\
\hline Acacia gourmaensis & 3.46 & 3.9 & 3.93 & 11.27 & Terminalia macroptera & 0.77 & 0.55 & 0.54 & 1.86 \\
\hline Mitragyna inermis & 3.08 & 3.2 & 2.98 & 9.26 & Phylanthus sp. & 0.38 & 0.5 & 0.14 & 1.02 \\
\hline Capparis tomentosa & 2.69 & 2.7 & 3.39 & 8.74 & Terminalia $\mathrm{sp}$. & 0.38 & 0.5 & 0.14 & 1.02 \\
\hline Azadirachta indica & 2.69 & 3.2 & 2.85 & 8.73 & Albizia zigya & 0.38 & 0.46 & 0.14 & 0.98 \\
\hline Mimosa sp. & 2.69 & 2.9 & 2.85 & 8.42 & Capparis sp. & 0.38 & 0.46 & 0.14 & 0.98 \\
\hline Piliostigma reticulatum & 2.69 & 2.7 & 2.57 & 7.96 & Combretum micrantum & 0.38 & 0.46 & 0.14 & 0.98 \\
\hline Ficus gnacalofarca & 1.92 & 2.5 & 2.3 & 6.67 & Crataeva adanonii & 0.38 & 0.46 & 0.14 & 0.98 \\
\hline Ziziphus spina christi & 1.92 & 1.7 & 1.76 & 5.42 & Bombax costatum & 0.38 & 0.28 & 0.14 & 0.8 \\
\hline Combretum lecardii & 1.54 & 1.1 & 2.17 & 4.82 & Cadaba farinosa & 0.38 & 0.28 & 0.14 & 0.8 \\
\hline Ximenia americana & 1.92 & 1.8 & 1.49 & 5.2 & Capparis fascicularis & 0.38 & 0.28 & 0.14 & 0.8 \\
\hline Grewia flavescens & 1.92 & 2.2 & 1.22 & 5.33 & Combretum glutinosum & 0.38 & 0.28 & 0.14 & 0.8 \\
\hline Ziziphu smauritiana & 1.92 & 2 & 1.22 & 5.11 & Combretum mollis & 0.38 & 0.28 & 0.14 & 0.8 \\
\hline Senna sp. & 1.54 & 1.8 & 1.36 & 4.67 & Combretum sp. & 0.38 & 0.28 & 0.14 & 0.8 \\
\hline Tamarindus indica & 1.54 & 1.3 & 1.36 & 4.23 & Daniellia oliveri & 0.38 & 0.28 & 0.14 & 0.8 \\
\hline Gardenia aquala & 1.54 & 1.7 & 0.81 & 4.08 & Entada africana & 0.38 & 0.28 & 0.14 & 0.8 \\
\hline Acacia $\mathrm{sp}$ & 1.15 & 0.8 & 1.22 & 3.2 & Grewia bicolor & 0.38 & 0.28 & 0.14 & 0.8 \\
\hline Combretum nigricans & 1.15 & 0.8 & 1.22 & 3.2 & Lannea barteri & 0.38 & 0.28 & 0.14 & 0.8 \\
\hline Dalbergia melanoxylon & 1.15 & 0.8 & 1.22 & 3.2 & Terminalia albida & 0.38 & 0.28 & 0.14 & 0.8 \\
\hline Senna sieberiana & 1.15 & 0.8 & 1.22 & 3.2 & Vitex doniana & 0.38 & 0.28 & 0.14 & 0.8 \\
\hline
\end{tabular}

The impact of firewood exploitation on the specific contribution of the herbaceous stratum

There is a close relationship between the frequency of woody species and the specific contribution of the herbaceous stratum. When the trees are excessively destroyed, the herbaceous stratum is more considerable. There is a recolonization of vegetation by herbaceous. In Table 16, the most represented herbaceous strata are
Senna occidentalis, Cyperus esculentus, Lagerra pterodonta, Corchorus olittorius and Tribulus terrestris $(\mathrm{Fa}=100 \%, \mathrm{Fr}=2.86 \%$ and $\mathrm{Cs}=0.03 \%)$.

The massive presence of these species in those areas results from their capacities to dominate the different environment. The Nenphea spp. $(\mathrm{Fa}=16.67) \mathrm{Fre}=0.50$, $\mathrm{Cs}=0$ the Dactyloctenium aegyptium $(\mathrm{Fa}=16.67, \mathrm{Fr}=0.44$, $\mathrm{Cs}=0$ ) species are less represented.

Table 16. Absolute frequency (Fa \%) relative frequency (Fr \%) and specific contribution (Cs \%) of the herbaceous.

\begin{tabular}{llllllll}
\hline Scientific names & Fa & Fr & Cs & Scientific names & Fa & Fr & Cs \\
\hline Senna occidental & 100 & 2.9 & 0.03 & Sesbania sesban & 50 & 1.5 & 0.01 \\
Cyprus esculentus & 100 & 2.9 & 0.03 & Ipomea aquatiqua & 50 & 1.5 & 0.01 \\
Laggera pterodonta & 100 & 2.9 & 0.03 & Euphorbia sp. & 50 & 1.4 & 0.01 \\
Corhorus olittorius & 100 & 2.9 & 0.03 & Eleusine indica & 50 & 1.4 & 0.01 \\
Tribulus terrestris & 100 & 2.9 & 0.03 & Bidens pilosa & 50 & 1.4 & 0.01 \\
Chromoleina odorata & 25 & 2.9 & 0.03 & Triumpeta pentandra & 50 & 1.4 & 0.01 \\
Eragrostis tremula & 92 & 2.6 & 0.03 & Penicetum purpurium & 50 & 1.3 & 0.01 \\
Hyptis sp. & 92 & 2.6 & 0.03 & Senna tora & 50 & 1.3 & 0.01 \\
Sida rhombifolia & 92 & 2.6 & 0.03 & Penicetum pedicellatum & 50 & 1.3 & 0.01 \\
Eragrostis aspera & 83 & 2.4 & 0.02 & Corhorus tridens & 50 & 1.3 & 0.01 \\
Mariscus spp. & 83 & 2.4 & 0.02 & Cenchrus biflorus & 50 & 1.3 & 0.01 \\
\hline
\end{tabular}




\begin{tabular}{llllllll}
\hline Scientific names & Fa & Fr & Cs & Scientific names & Fa & Fr & Cs \\
\hline Imperata cylindrica & 83 & 2.4 & 0.02 & Vernonia perrottetii & 42 & 1.3 & 0.01 \\
Schwenkia americana & 75 & 2.2 & 0.02 & Tacca leontopetaloides & 42 & 1.3 & 0.01 \\
Indigofera pilosa & 75 & 2.2 & 0.02 & Physalis angulata & 42 & 1.3 & 0.01 \\
Penicetum sp. & 75 & 2.2 & 0.02 & Bulbostylis hispidula & 42 & 1.3 & 0.01 \\
Aristida adscensionis & 75 & 2.1 & 0.02 & Sporobolus festivus & 42 & 1.3 & 0.01 \\
Commelina benghalensis & 75 & 2.1 & 0.02 & Citrullus lanatus & 42 & 1.2 & 0.01 \\
Tridax procumbens & 67 & 1.9 & 0.02 & Kyllinga tenuifolia & 42 & 1.1 & 0.01 \\
Setaria pumila & 67 & 1.9 & 0.02 & Leucas martinicensis & 42 & 1.1 & 0.01 \\
Hibuscus spp. & 67 & 1.9 & 0.02 & Mitracarpus villosus & 42 & 1.1 & 0.01 \\
Commelina forskalei & 67 & 1.8 & 0.02 & Walthera indica & 42 & 1.1 & 0.01 \\
Euphorbia hirta & 67 & 1.8 & 0.02 & Melinis repens & 33 & 0.9 & 0.01 \\
Cyprus rotundus & 58 & 1.6 & 0.02 & Brachiaria lata & 33 & 0.9 & 0.01 \\
Asparagus schweinfurthii & 58 & 1.6 & 0.02 & Mollugo nudicaulis & 33 & 0.9 & 0.01 \\
Crotalaria spp. & 58 & 1.6 & 0.02 & Ipomoea sp. & 25 & 0.7 & 0.01 \\
Euphorbia heterophylla & 58 & 1.6 & 0.02 & Ludwigia hyssopifolia & 25 & 0.7 & 0.01 \\
Phyllantus amarus & 58 & 1.6 & 0.02 & Cynodon dactylon & 25 & 0.7 & 0.01 \\
Zornia glochidiata & 58 & 1.6 & 0.02 & Brachiaria villosa & 25 & 0.7 & 0.01 \\
Ocimum canum & 50 & 1.5 & 0.02 & Nenphea spp. & 17 & 0.5 & 0 \\
Portulaca oleracea & 50 & 1.5 & 0.02 & Dactyloctenium aegyptium & 17 & 0.4 & 0 \\
Cleome monophylla & 50 & 1.5 & 0.01 & & & \\
\hline
\end{tabular}

The impact of firewood exploitation on the floristic homogeneity of the vegetation

The results of the floristic homogeneity test shown in Fig. 12 are clear facts that the frequency with heterogeneous index is for woody species of $\geq 10$ circumference and those of herbaceous species. The non-essential of those species are many and their dissemination is done accidentally. The vegetation of the research area which is under anthropic pressure is heterogeneous. Among the woody species the accidental subjects are Ficus spp. and Anogeissus leiocarpus; the scare species are Ceiba pentandra, Vitelaria paradoxa and Parkia biglobosa; the dominant species are Mitragyna inermis and Balanites aegyptiaca; the most dominant species are Acacia nilotica, Acacia seyal, Acacia gourmaensis and Capparis spp. Among the herbaceous species, the accidental species are Hyptis spp. and Eragrostis tremula; the scare species are Aristida adscensionis and Schweinkia american; the dominant species are Sida rhombifolia and Imperata cylindrica. The most dominant species are Senna tora, Pennicetum spp., Commelina spp. and Corchorus olittorius. There is a close relationship among the frequency index curves. More the vegetation is less exploited for firewood (woody species with $\geq 10 \mathrm{~cm}$ ), more there is a great number of most frequent or frequent woody species.

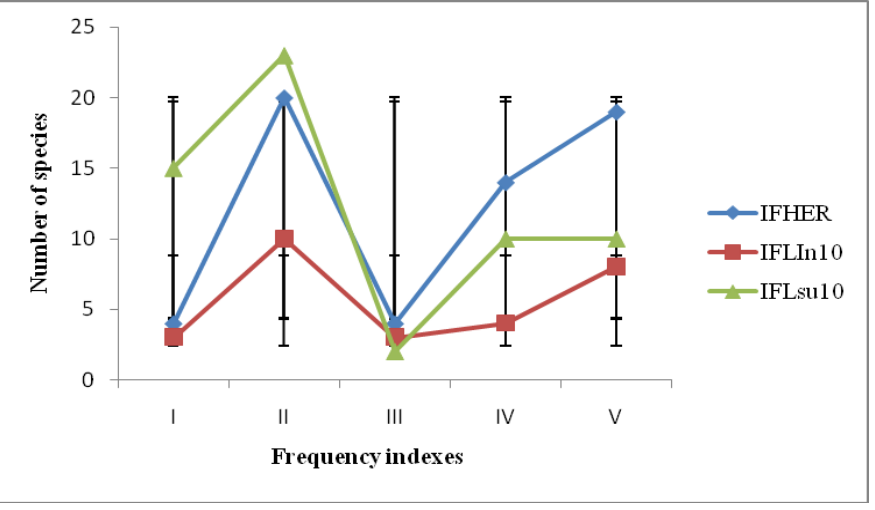

Fig. 12: Homogeneity test for herbaceous and woody species. IFHER: herbaceous frequency index; IFLin10: frequency index of woody species with $<10 \mathrm{~cm}$ circumference; IFLsu10: frequency index of woody species with $\geq 10 \mathrm{~cm}<$ circumference.

\section{The impact of firewood exploitation on the} environment

From the surveys enquires, the ecosystem degradation $(81.7 \pm 2.36)$, the drop in the non woody species of forestry product $(75.8 \pm 2.36)$ and the temperature rise up

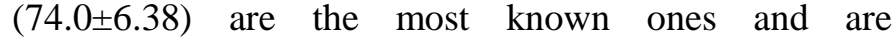
respectively the drawbacks of the firewood exploitation when the vegetation is overexploited for firewood. The direct consequence is the environment degradation with the destruction of animal habitats Table 17. 
Table 17. The consequence of firewood exploitation (\%).

\begin{tabular}{lllll}
\hline Consequences & Dourbali & Karnak & Bodro & Average \\
\hline Ecosystem deterioration & 80 & 80 & 85 & $81.67 \pm 2.36^{\mathrm{a}}$ \\
PFNL decline & 82.5 & 82.5 & 62.5 & $75.83 \pm 9.43^{\mathrm{a}}$ \\
Temperature rise up & 75 & 76 & 73 & $74.67 \pm 1.25^{\mathrm{a}}$ \\
Farming output drop & 33.5 & 77.5 & 52.5 & $54.50 \pm 18.02^{\mathrm{b}}$ \\
Rain drop out & 23 & 42 & 60.7 & $41.90 \pm 15.39^{\mathrm{b}}$ \\
Biodiversity loss & 16 & 24.5 & 27.5 & $22.67 \pm 4.87^{\mathrm{c}}$ \\
\hline
\end{tabular}

\section{Drop in the woody species and the desert advance}

The distance existing between the Ndjamena town and brush is exponentially growing these two years of the decade (Table 18).

Table 18. Variation in terms of distances for firewood fetching in the area of study.

\begin{tabular}{llll}
\hline Years & Dourbali & Karnak & Bodro \\
\hline 1990 & $500 \mathrm{~m}$ & $300 \mathrm{~m}$ to $500 \mathrm{~m}$ & 200 to $400 \mathrm{~m}$ \\
2000 & $2 \mathrm{Km}$ & $1 \mathrm{Km}$ & $1 \mathrm{Km}$ \\
2006 & $10 \mathrm{Km}$ & $5 \mathrm{Km}$ & $3 \mathrm{Km}$ \\
2013 & $15 \mathrm{Km}$ & $10 \mathrm{Km}$ & $10 \mathrm{Km}$ \\
\hline
\end{tabular}

It moved from $10 \mathrm{Km}$ to $230 \mathrm{Km}$ within the years 1990 to 2013. At the level of the exploitation area, it stretches on $500 \mathrm{~m}$ to $20 \mathrm{Km}$ from $300 \mathrm{~m}$ to $500 \mathrm{~m}$ and from $200 \mathrm{~m}$ to
$400 \mathrm{~m}$ in Doubali, Karnak and Bodro respectively. This exponential growth in the distances to go and fetch firewood upholds the high demand in firewood in the three villages mentioned above and especially in big towns.

\section{The most threatened and exploited species as firewood}

More than six species are highly exploited as firewood in the three villages above. Among them, the Acacia nilotica is the most exploited $(93 \pm 13$. 37) with the highest percentage in the Bodro village (111). Species

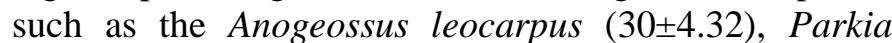

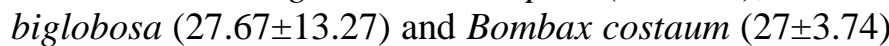
are the most threatened woody species which are under extinction (Table 19).

Table 19. List of the most exploited species as firewood.

\begin{tabular}{|c|c|c|c|c|c|c|}
\hline & Species & Family & Dourbali & Karnak & Bodro & Average \\
\hline \multirow{4}{*}{$\begin{array}{l}\text { Exploited species } \\
\text { as firewood }\end{array}$} & Acacia nilotica & Mimosaceae & 89 & 79 & 111 & $93 \pm 13.37$ \\
\hline & Acacia senegalensis & Mimosaceae & 62 & 83 & 75 & $73.33 \pm 8.65$ \\
\hline & Balanites aegyptiaca & Balanitaceae & 49 & 55 & 70 & $58 \pm 8.83$ \\
\hline & Combretum spp. & Combretaceae & 88 & 32 & 40 & $53.33 \pm 24.73$ \\
\hline \multirow{7}{*}{$\begin{array}{l}\text { Plant species under } \\
\text { extinction due to } \\
\text { firewood } \\
\text { exploitation }\end{array}$} & Anogeissus leiocarpus & Combretaceae & 24 & 34 & 32 & $30 \pm 4.32$ \\
\hline & Parkia biglobosa & Mimosaceae & 26 & 32 & 23 & $27 \pm 3.74$ \\
\hline & Bombax costatum & Bombacaceae & 18 & 28 & 31 & $25.67 \pm 5.56$ \\
\hline & Crataeva adansonii & Capparaceae & 21 & 9 & 21 & $17 \pm 5.66$ \\
\hline & Tamarindus indica & Cesalpiniaceae & 9 & 8 & 25 & $14 \pm 7.79$ \\
\hline & Diospyros mespiliformis & Ebenaceae & 13 & 9 & 17 & $13 \pm 3.27$ \\
\hline & Ceiba pentandra & Bombacaceae & 9 & 17 & 11 & $12.33 \pm 3.40$ \\
\hline
\end{tabular}

\section{Joint management and adjustment plan proposal against firewood exploitation}

Table 20 mainly shows joint adjustment measures taken by the local population to fight firewood exploitation. The prohibition of fresh wood $(86 \pm 5.10)$, the forester service strengthening of measures $(45.67 \pm 17.99)$ and the sanction against illegal wood exploiters $(27.67 \pm 17.33)$ are some of the measures put in place by authorities to restrict excessive firewood exploitation. This result confirms the application of the management measures taken by authorities for instance the ministry in charge of water and environment.

As for the development proposal plan, 7 (seven) proposals were put at the disposal of the population and the Chadian government to solve the back of environmental management and maintenance. The setting up by the government for a consultation framework of the stakeholders is required. The sensitization of the resident 
population on the firewood issue and the man's responsibility on the degradation or environmental maintenance. The setting up of some association or producer groups companies, traders and firewood exploiters. The demarcation of annual exploiting areas taking into account land ecosystems and the rotation of the forest destruction practices. The vulgarization of other forms of domestic power and the creation of other activities in terms income products. The recruitment and training of forestry agents at the local level is necessitated. The putting in place of a spatiotemporal and ecological follow-up for a better understanding of the vegetation dynamism the planting of trees in damaged areas as well as the scientific research boosting in this dominant evident.

Table 20. Local measures for joint management.

\begin{tabular}{lllll}
\hline Local measure & Dourbali & Karnak & Bodro & Rate \\
\hline Prohibition of fresh wood destruction & 88 & 91 & 79 & $86 \pm 5.10^{\mathrm{a}}$ \\
Strengthening of forestry agent & 71 & 31 & 35 & $45.67 \pm 17.99^{\mathrm{b}}$ \\
Sanctions against illegal farmers & 52 & 18 & 13 & $27.67 \pm 17.33^{\mathrm{c}}$ \\
Tax increases & 11 & 15 & 8 & $11.33 \pm 2.87^{\mathrm{c}}$ \\
Reforestation & 4 & 3 & 3 & $3.33 \pm 0.47^{\mathrm{d}}$ \\
Creation of protected area & 0 & 0 & 0 & $0 \pm 0.00^{\mathrm{e}}$ \\
Proposal of alternative energy source & 2 & 0 & 1 & $1 \pm 0.82^{\mathrm{e}}$ \\
Others & 1 & 3 & 0 & $1.33 \pm 1.25^{\mathrm{e}}$ \\
\hline
\end{tabular}

\section{Discussion}

The Firewood is the energy source in the Chadian republic. AEDE (2002) point out that wood as energy is the most exploited energy source up to (90\%) in many Chadian households, Sia et al. (2007) show that people use firewood up to $84 \%$ in Burkina Fasso households. It is mostly exploited by men for this activity requires not only physical strength, but also the presence of immigrant workers specially who settled there for firewood exploitation remain agriculture and energy needs (Schure et al., 2011). In fact the demographic boom is the main cause of the high demand in farm products and domestic energy. This result corroborates the one which shows that slash- and-burn cultivation is the mains cause of deforestation and the degradation in the central African forests. The others causes known negligible are the many practice uses such as sculpture woods, energy wood, services wood, traditional pharmacopeia, food industries, fodders and gum arabic. Non corroborations results have shown that species such as Syzygium guineense, Vitellaria paradoxa and Parkia biglobosa are the most used in food industries traditional pharmacopeia, service wood and fodder in Cameroon (Tchobsala, 2011). The population over used firewood. This usage of the firewood is higher than that of Jamin et al. (2003) which shows a usage quantity of $1.65 \mathrm{~kg}$ in Maroua Region. Firewood is not only used in household activities but also in marketing. In that same region, there exist two marketing systems. Those two systems are mostly found in organized and informal sector. This result is different from the one of Sia et al. (2007) in Burkina Faso who identified one sector with an organized and formal system. The firewood income revenue is vital for family savings. This results also corroborate with the one of Schure et al. (2011), Who highlighted the fact that the income generated from the energy woods system are put on active service to pay for the basic needs which serve as reinvestments in other activities of farming in particular. Although firewood exploitation is vital for family saving, its exploitation without any inspection causes severe damages to man, the environment and biodiversity. In Cameroon, Maponmetsem et al. (1997) and Tchobsala (2011) have revealed that the deforestation for firewood purpose becomes and income generator and the consequence of such act on the environment is alarming. It is the source of many diseases as emphasize by Celestine et al. (2005) and they cause phytopathology to some trees (Ouedraogo et al., 2003). Firewood exploitation is at the source of soil degradation and productivity drop out (Dobie, 2001). Tchobsala (2011) shows that the Hymenocardia acida is the most used specie as firewood in the Adamaoua savannah while Schure et al. (2011) shows that the Melicia excels and the Millettia laurantii are the most solicited in Kinshasa. These species are under the extinction thread.

\section{Conclusion and views}

Wood consumers and producers are directly involved in firewood exploitation. Firewood exploitation rate depends on the periods of the Year. The highest moment of firewood exploitation stretches from December to the month of April because it during that period that farm works drop out. The main reasons for firewood exploitation were mostly for farming domestic household energy needs and a high demand for firewood. The 
output, the consumption and the exploitation of firewood are more noticeable in the Bodro village. On the socio economic plan the firewood field contributes at the large scale to the improvement of the living condition of the people. The profits resulting from firewood exploitation are more advantageous to the wholesalers who earn about 8833.33 per day against the meager sum of 3833.33FCFA earned by the lumberjacks. However, the firewood exploitation has a negative impact because it is the source of eye problems and respiratory problems.

On the environment domain, there is the degradation and the decline of the planted tree and shrub savannah (floristic resources and poor diversity indications) consisting of $500 \mathrm{~m}$ to $15 \mathrm{~km}$ within the space of 23 years, the decline in non woody species of forestry products, the uneven distribution of the vegetation in the area of research, the homogeneity of the vegetation, the sanitary stat of the threatening vegetation, the extinction of plant biodiversity. The prohibition of green wood destruction is the main method of managing sustaining resource of wood. It is therefore important to examine the productive potential solicited species of fire, to assess the carbon sequestration rate solicited species to draw up a development plan for the whole residents of the basin and different formations of vegetation combined with carbon taxation.

\section{Conflict of interest statement}

Authors declare that they have no conflict of interest.

\section{Acknowledgement}

We would like to extend our gratitude to the three villages Dourbali, Karnak and Bodro who joined us for the success of this research work and helped us to find sustainable solutions for the safeguarding of the socio economic and environmental impacts of firewood exploitation from the Ndjamena supply basin as wood energy (Chad).

\section{References}

AEDE, 2002. Plan Directeur d'Approvisionnement de N'Djamena en énergie Domestique. 30p.

Antonios, P., 2002. Le développement agricole durable: Rêve ou réalité ? Le courrier ACP-EU. 193, 28-29.

Begon, M., Harper, J.L., Towsend, C.R., 1987. Ecology: Individuals. Populations and Communities. Blackwel Scientifics Publications, Oxford. London. Edinburgh. Boston. Palo Alto. Melbourne. 876p.
Braun-Blanquet, 1932. Plant Sociology. The Study of Plant Communities. McGraw Hill, New York. 439p.

Célestine, M., Medou., Jean-Philippe, W., 2005. Évaluation des impacts socio-économiques: cas d'unité forestière d'aménagement de la compagnie forestière Leroy-Gabon. Sciences de l'environnement. URL: http://vertigo. revues.org/4392.

Diop, E. H., 2000. Les biotechnologies et l'espoir de vaincre la famine et la malnutrition dans le monde. A Biotech. 4. 5p.

Dobie, P., 2001. Poverty and the drylands. In: Global Drylands Imperative. Challenge Paper. UNDP. Nairobi (Kenya). $16 \mathrm{p}$.

FAO, 1997. State of the World's Forest. World End Publication, Oxford, UK. pp.1-5.

Hien, V., Sedogo, P.M., Lompo, F., 1994. Gestion de la fertilité des sols au Burkina Faso: Bilan et perspectives pour la promotion de systèmes agricoles durables dans la zone soudano-sahélienne. In: Cattier B.M et De Gorandi V.C (Eds.). Séminaire Régional Organisé par la FAO et le CIRAD avec le Concours du Gouvernement Français. Dakar/Sénégal. pp.47-60.

INSEE, 2009. Résultats globaux. Deuxième recensement général de la population et de l'habitat (RGPH2). République du Tchad. 88p.

Jamin, J.Y., Seiny Boukar, L., Floret, C., 2003. Savanes Africaines: des espaces en mutation. des acteurs face to de nouveaux défis. Actes du colloque. mai 2002. Garoua. Cameroun. Prasac. N'Djamena. Tchad-Cirad. Montpellier, France.

Mapongmetsem, P.M., Akoua, Z.CH., 1997. Situation de bois de feud dans les savanes humides de l'Adamaoua. Flamboyant. 42, 29-33.

Ouedrago, D., Zahongo, P., 2003. Etude sur l'impact économique du RPTES dans le centre Nord et le Centre Ouest u Burkina Faso: Analyse et implications pour des actions futures. Rapport final UICN. 64p.

Palmberg-Lerche, C., 1997. Vers un cadre cohérent pour la conservation et l'utilisation durable des ressources génétiques forestières. FAO, Rome. Ressour. Génét. Forestièr. 24, 16-20.

Pielou, E. C., 1994. Biodiversity versus Old-style Diversity: Measuring Biodiversity for Conservation. In : T. J. B. Boyle et Boontaweeéds.

Schure, J., Ingram, V., Akalakou-Mayimba, 2011. Bois énergie en RDC: Analyse de la filière des villes de Kinshasa et Kisangani. Yaoundé. CIFOR. Projet Makala (http://makala.cirad.fr/). 11p.

Sia, C., Zoubi, N., Fanta, C.K., Tenga, R., Aboubacar, G., Inombè, H.S., Silamane, K., 2007. Analyse des impacts financiers et économiques de la filière bois-énergie organisée approvisionnant la ville d'Ouagadougou. République de Burkina-Faso. Ministère de l'environnement et du cadre de vie. secrétariat général. Rapport de travail sur le Bois - énergie. pp.9-25.

Tchobsala, 2011. Impact des coupes de bois sur la végétation naturelle de la zone péri-urbaine de Ngaoundéré 
(Adamaoua). Thèse de Doctorat Ph.D. Université e Yaoundé I. 204p.

Tchotsoua, M., Mapongmetsem, P.M., Tago, M., 2000. Urbanisation. Crise économique et dynamique de l'environnement en milieu soudanien d'altitude: le cas du plateau e N'gaoundéré. Revue de géographie du Cameroun. Société et environnement au Cameroun 14(2), 225-249.
Wanders, I.T.H.V., 2000. Restauration et conservation des forets dans le département du Noren. Résumé des expériences du projet. FORM Ecology consultants BV. Ridderstraat 28051 EH Hattem. Pays bas. 32p.

Yonheu, S., 1993. Végétation des pâturages de l'Adamaoua (Cameroun). Ecologie et potentialité pastorales. Thèse Doctorat (Sciences Biologiques). Univ. Rennes I. France. 207 p.

\section{How to cite this article:}

Tchobsala, Adamou, I., Noé, K., 2016. The socio economic and environmental impacts of firewood exploitation from the Ndjamena supply basin as wood energy (Chad). Int. J. Curr. Res. Biosci. Plant Biol. 3(10), 57-75. doi: http://dx.doi.org/10.20546/ijcrbp.2016.310.008 